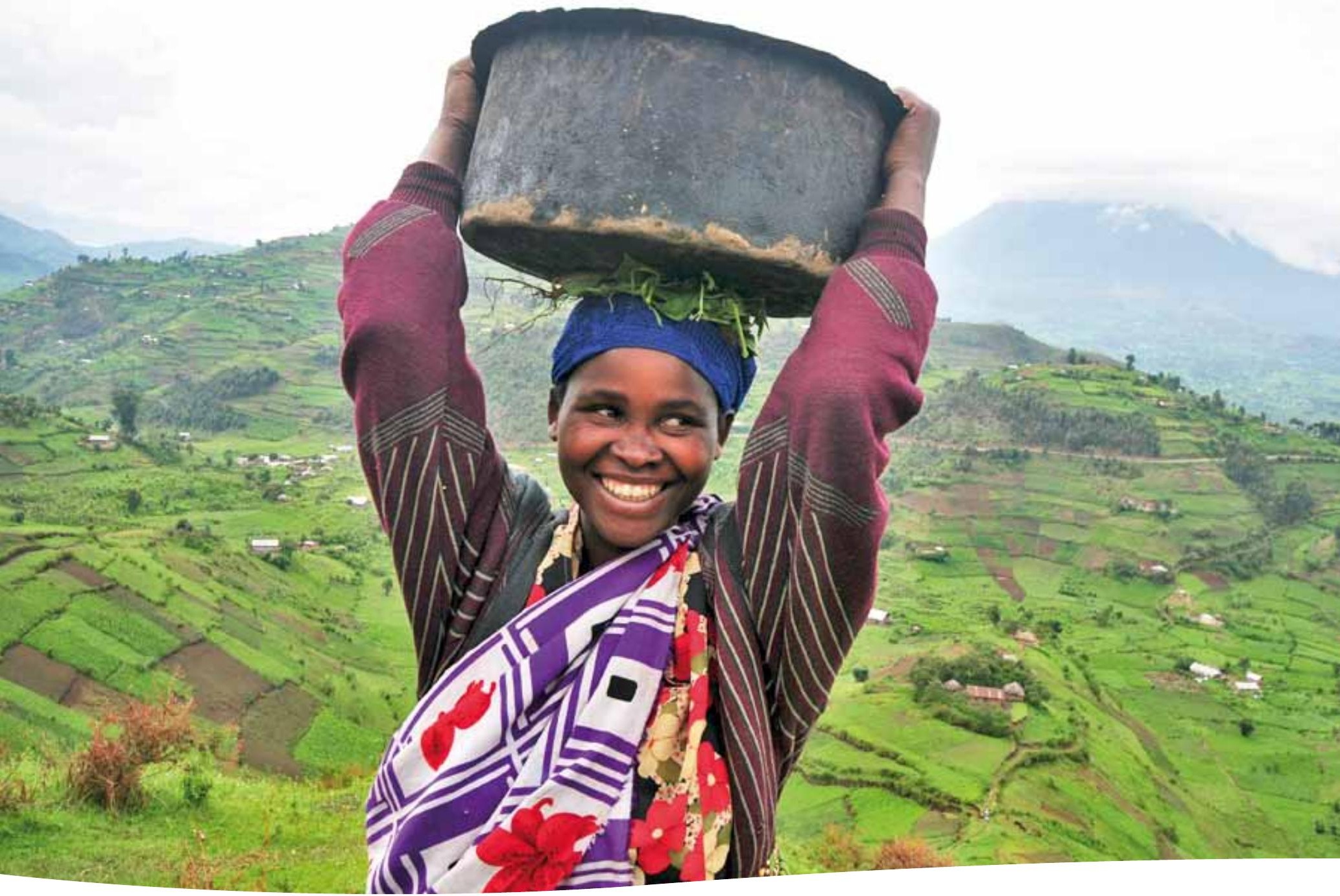

\title{
Gender, tenure and community forests in Uganda
}

Abwoli Y. Banana

Mohamed Bukenya

Eusobio Arinaitwe

Betty Birabwa

Silvester Ssekindi 

Working Paper 87

\section{Gender, tenure and community forests in Uganda}

Abwoli Y. Banana

Mohamed Bukenya

Eusobio Arinaitwe

Betty Birabwa

Silvester Ssekindi 
Working Paper 87

(c) 2012 Center for International Forestry Research All rights reserved

Banana, A. Y., Bukenya, M., Arinaitwe, E., Birabwa, B. and Ssekindi, S. 2012 Gender, tenure and community forests in Uganda. Working Paper 87. CIFOR, Bogor, Indonesia.

Cover photo by Neil Palmer/CIAT

Faces of southwestern Uganda

CIFOR

Jl. CIFOR, Situ Gede

Bogor Barat 16115

Indonesia

$\mathrm{T}+62(251) 8622-622$

$F+62$ (251) 8622-100

E cifor@cgiar.org

\section{www.cifor.org}

Any views expressed in this publication are those of the authors. They do not necessarily represent the views of CIFOR, the authors' institutions or the financial sponsors of this publication. 


\section{Table of contents}

Abbreviations $\quad$ v

Acknowledgements

Executive summary vii

1 Introduction 1

1.1 Management of forestry resources in Uganda $\quad 1$

1.2 The role of women in forest management in Uganda 1

1.3 Factors that influence participation of women in sustainable forest management 2

2 Description of the study and extent of involvement of external actors 4

$\begin{array}{lll}2.1 & \text { Description of study area } & 4\end{array}$

2.2 Criteria for selecting study districts and sites $\quad 5$

3 Methodology 6

3.1 Assessing the extent to which gender features in projects and programmes 6

3.2 Assessing the extent to which gender features in forest use and management in forest-adjacent

3.3 Exploring the extent to which gender features in local councils/committees in the study districts 6

$\begin{array}{ll}3.4 \text { Data Analysis } & 7\end{array}$

4 Results $\quad \mathbf{8}$

4.1 Extent to which gender features in organisational projects and programmes not specifically involved in

forestry 8

4.2 Extent to which gender features in organisational projects and programmes specifically involved in forestry $\quad 10$

4.3 Extent to which gender features in forest communities 12

4.4 Extent to which gender features in local councils/committees for forest/environmental management in the study districts

$\begin{array}{lll}4.5 & \text { Lessons learned from the study and recommendations } & 27\end{array}$

$\begin{array}{ll}4.6 \text { Conclusions } & 30\end{array}$

References

Annexes

1 Criteria for site selection $\quad 34$

2 Forest adjacent communities, the actors and state of forest studied 35 


\section{List of tables and figures}

\section{Tables}

1 Extent to which gender features in organisational projects and programmes $\begin{array}{lr}\text { not specifically involved in forestry } & 8\end{array}$

2 Perceived success stories by organisations studied 9

3 Obstacles prohibiting organisations from addressing gender issues 9

4 Organisational strategies to integrate gender 11

5 Projects/organisations specifically involved in forestry and tree planting 11

6 Formal user-groups studied $\quad 14$

7 Benefits that accrue to members in registered forest-user groups 14

8 Roles carried out by men and women $\quad 17$

9 Forest-harvesting activities 21

10 Composition of respondents interviewed 24

11 Gender composition of committees where respondents serve 25

12 Mandate of various committees 26

13 Forest-related decisions made in committees as reported by respondents 27

14 Examples of decisions influenced by women councillors $(\mathrm{N}=10) \quad 27$

15 Analysis of gender issues in the districts and what can be done to improve
women's participation

\section{Figures}

1 Lake Victoria Crescent covering the study districts of Mpigi, Masaka and Rakai 4

2 Local government structure in Uganda following the 1997 Local Government Act 24 


\section{Abbreviations}

AUPWEA

BCFCP

CBOs

CDOs

CFM

CIFOR

CFR

CODECA

DDP

DEOs

DFOs

DFS

EA

EC

FAO

FID

FIEFOC

FOWODE

GEF

GRN

IFRI

IRDI

MADDO

MTGC

MWE

NAADS

NaFORRI

NBI

NFC

NFA

NGOs

NTFPs

NUCAFE

SAS

SCC Vi

SPGS

PFE

UBOS

UFRIC

UNDP

UTGA
Association of Uganda Professional Women in Agriculture and Environment

Budongo Community Forest Conservation Project

community-based organisations

Community Development Officers

collaborative forest management

Center for International Forestry Research

Central Forest Reserve

Community Development Conservation Agency

District Development Plan

District Environmental Officers

District Forest Officers

District Forest Services

Environmental Alert

Environmental Committee

Food and Agriculture Organization of the United Nations

Forest Inspection Division

Farm Income Enhancement and Forest Conservation

Forum for Women in Democracy

Global Environment Facility

Green Resources Norway

International Forestry Resources and Institutions

Integrated Rural Development Initiative

Masaka District Dairy Organisation

Masaka Tree Growing Cluster

Ministry of Water and Environment

National Agricultural Advisory Services

National Forestry Resources Research Institute

Nile Basin Initiative

New Forest Company

National Forest Authority

non-governmental organisations

non-timber forest products

National Union of Coffee Agribusinesses and Farm Enterprises

Senior Accountants Secretary

Swedish Cooperative Centre Agroforestry

Sawlog Production Grant Scheme

Permanent Forest Estate

Uganda Bureau of Standards

Uganda Forestry Resources and Institutions Centre

United Nations Development Programme

Uganda Timber Growers Association 


\section{Acknowledgements}

We would like to thank all the people who cooperated with us by providing information for the study: executive members and staff of NGOs, government officials in ministries and agencies, and the District Forest Officers in Mpigi, Masaka and Rakai. We are grateful to D. Waiswa of the School of Forestry, Biodiversity and Tourism for preparing the study map. We wish to express our heartfelt gratitude to the Austrian Development Agency
(ADA) for availing the funds and to CIFOR for managing and guiding the study. We are also grateful to AUPWAE, our local collaborating partners in this project, for their good leadership. Finally, we are grateful to Esther Mwangi and Anne Larson (project coordinators) of CIFOR for their advice and encouragement and to the reviewer for her useful comments. 


\section{Executive summary}

Over the past century, the management of forest resources in Uganda has vacillated from a centralised to a decentralised approach. With the Forest Act in 1993, the country began a new round of governance reforms that devolved ownership and management of central forest reserves to local governments. Four years later, the Local Government Act transferred management functions over forest reserves to the districts and sub-counties. By 2000, however, the deforestation rate - already the highest in eastern Africa - had accelerated.

Despite the trend toward greater participation of communities in forest management, women have been largely shut out of decision making. Yet women are important actors, depending on forest resources for subsistence, as safety nets and even for income. Through this study, the researchers wish to contribute toward improving women's tenure rights to forests through their increased participation in communityforest user-groups with regard both to decision making and livelihood benefits.

The study, which focused on the districts of Mpigi, Masaka and Raki in the Lake Victoria agroecological zone, had these key findings:

- Organisations and programmes that were not forest-specific were to some extent aware and concerned about gender issues; several had strategies to increase women's participation in their activities. Although some government forestry agencies were aware of the legal requirement to integrate gender, organisational projects and programmes specifically involved in forestry do not prominently feature gender issues.

- Low levels of gender integration and affirmative actions within organisations, programmes and in local governments arise in part due to inadequate budgets for gender mainstreaming coupled with limited staff training in gender issues; limited numbers of women in leadership of forest projects and programmes to articulate women's needs and desires in the forest sector; and gender insensitivity by policy makers and professionals in the forest sector.

- The quality and extent of women's participation in decision making in forest management appear to be enhanced when women join formal forest user-groups. Knowledge of laws, access rights and the concept of participation were also better understood among members of formal forest user-group associations; in communities without these formal associations, most people did not understand the concept of participation or rights in respect to forest management.

- The major obstacles hindering women's participation in on-farm tree planting and commercial plantation initiatives are gender disparities in land ownership; cultural norms and practices; heavy domestic work loads; limited access to credit and farm inputs; and provision of seedlings of tree species not preferred by women.

- The Local Government Act of 1997 envisioned that local communities could participate in decision making about the environment and forestry issues through village councils and through the councillors elected to serve in parish, sub-county and district councils. However, most of these local government organs have been dormant over the last 10 years. Only the district and sub-county councils are still functioning and yet most women have no access to them.

- Most communities have contact with external actors such as NGOs. However, most NGOs fund projects aimed at improving agriculture production (such as the provision of improved agricultural seeds and improved breeds of goats, pigs and cows); only a few fund forest-management activities and nature conservation. Women in many communities belong to several women's groups funded by NGOs. Through these groups, women can attend capacity-building seminars and access loans from micro-finance institutions. Equipped with better information and finances, women may be in a better position to participate effectively in the management of forest resources in the country. 



\section{Introduction}

\subsection{Management of forestry resources in Uganda}

There are about 4.9 million hectares (ha) of forest in Uganda (24\% of the present total land area) (Forest Dept. 2003). The forest resources comprise areas classified as savanna woodland $(80.5 \%)$, natural forest (tropical high forest, 18.7\%) and forest plantations (less than 1\%). In terms of land ownership, $70 \%$ of the forest area is on private and customary land, while $30 \%$ is in the permanent forest estate (PFE), such as forest reserves (central and local), national parks and wildlife reserves. However, Uganda has the highest annual rate of deforestation in eastern Africa. Forest cover fell by 15\% between 1990 and 2005, and the deforestation rate has accelerated since 2000 (FAO 2007). Most deforestation occurs on private and customary forests.

The management of forest resources in Uganda has vacillated from centralisation to decentralisation over the past century (Turyahabwe et al. 2006). The first attempt to decentralise was in 1939-1947 with registration establishing local forest reserves under the districts' administration. Recent governance reforms in the forest sector were initiated in 1993, when the Uganda government devolved the ownership and management of central forest reserves to local governments. The high rate of deforestation was cited as one of the major reasons for the governance reforms. The 1997 Local Government Act transferred management functions over forest reserves to the districts and sub-counties.

Under the new Forest Act 2003, a Forest Inspection Division (FID) in the Ministry of Water and Environment was formed to supervise the activities of two bodies: the newly created and autonomous National Forest Authority (NFA), which became responsible for central forest reserves, and the District Forest Services (DFS), which was created to manage local forest reserves and to offer advisory services to private and customary forest owners. These three institutions replaced the Forest Department (Republic of Uganda 2003).
The National Forest Policy 2001 (Republic of Uganda 2001) and the National Forestry and Tree Planting Act 2003 (Republic of Uganda 2003) legally permitted the participation of adjacent forest communities in the management of forestry resources in the country through collaborative forest management (CFM) arrangements with the NFA or DFS (Republic of Uganda 2003).

\subsection{The role of women in forest management in Uganda}

Women are important actors in forest management. However, despite the existence of enabling laws and gender policy in the country, women's involvement in decision making is limited and has not kept pace with current governance reforms in the broader political and economic systems in general and in forest management in particular (AUPWEA 2011). Recent approaches to forest management in many developing countries have tended towards greater community participation by devolving authorities to local communities. Despite this trend, increasing evidence suggests that women, who are among the poorest of the poor, and who depend on forest resources for subsistence, as safety nets and even for income, continue to be marginalised in processes of rule making and in the distribution of the benefits of forest resources (Mwangi et al. 2011). There is therefore a need to understand and to remedy the continued lack of involvement of women in forest management. Increasing global interconnectedness, international trade and climate change will likely add to the vulnerability of women's rights to resources in rural settings in developing countries such as Uganda.

The goal of this research is to contribute to improve women's tenure rights to forests through their increased participation in community forest user-groups with regard both to decision making and livelihood benefits. The purpose of the project is to enhance stakeholder uptake of institutional and policy innovations to promote women's participation, specifically regarding the way in which community forestry-related decisions include women and reflect their particular interests. 
The study attempted to answer the following questions:

1. To what extent are women involved in decision making, agenda definition and benefit-sharing at multiple levels of governance (local, district and regional scales)? What are the main impediments to their greater participation?

2. Do external actors such as NGOs and governments (local, regional and national) support women's participation in community forest management? In what way and with what outcomes?

3. What kinds of governance arrangements, processes and structures can be designed to encourage the inclusion of women in community forestry?

This research report presents findings from three districts of Uganda: Mpigi, Masaka and Rakai, which are part of the Lake Victoria agroecological zone. This is useful in formulating policy and designing intervention projects intended to enhance women's participation in forest management in Uganda.

\subsection{Factors that influence participation of women in sustainable forest management}

The National Forest Policy (Republic of Uganda 2001) states that the government will ensure the integration of gender concerns and issues into the development of the forestry sector. Strategies for implementing the policy will specifically account for gender differences in the perceptions and uses of forest products. This will include efforts to:

- Increase security of tenure over forest resources for women and youth.

- Encourage active participation of women and youth in decision making, resource management and sharing of benefits.

- Promote changes in attitudes and organisational cultures to break down gender barriers and to provide mutual respect and dignity for all people irrespective of social group, gender or background.

Gender barriers in forest management among the Baganda, an ethnic group found in the Buganda Kingdom in Central Uganda, were extensively studied by Howard et al. (2007). The study showed that the legal, customary and normative rights regimes around natural resources constitute and reflect unequal gender power relations; the regimes ensure women's access to spaces and species that are essential to fulfilling their livelihood obligations, while reinforcing women's orientation toward production for subsistence. Ultimately, they confer greater privileges and status upon men.

Rocheleau and Edmunds, 1998 demonstrate that access to different plant and tree resources in different societies, is complex. This access is characterised by nested and overlapping rights that are politically, socioeconomically and culturally determined. Often this nestedness and overlapping is related to, customary tree and land tenure, which confers different 'bundles of rights' upon different users depending on their sex, age and kinship.

In addition to cultural and social norms, Muhereza (2006), Buyinza and Naguula (2007) and Kugonza et al. (2009) have stressed several other major constraints to women's participation: the imbalance in sharing revenue accruing from tree products, unequal opportunity for conservation education and training, the general under-valuation of women's roles in sustainable forest management and lack of consideration of women's specific needs regarding forestry. Evidence suggests that the lack of consideration of women's needs arises from their lack of participation in policy formulation and decision making. Policy makers, who tend to be male, lack data and information and are not sensitive to women's needs and aspirations.

The National Forest Policy 2001 introduced governance reforms in the forest sector. The policy institutionalised development of collaborative partnerships with several categories of actors, including rural communities, for the sustainable management of forests. The number of actors involved in forest management expanded to include nongovernmental organisations (NGOs), community-based organisations (CBOs), local government, local communities, forest associations, private farmers and private companies. The government's strategy was to develop robust community institutions to ensure transparent decision making and accountability in the forest sector. The new Forest Policy also recognised the importance of forests for livelihoods and incomes of communities living adjacent to 
forests. These elements are fundamental for enhancing community interest in sustainable forest management. Guidelines were put in place for the implementation of partnership arrangements in the forest sector (Republic of Uganda 2003). The guidelines emphasised adequate representation and participation of women, men and vulnerable groups and the equitable sharing of forest benefits and responsibilities.

Although the legal and policy environment is supportive, there is evidence suggesting that women continue to be marginalised in processes of rule making in many partnership arrangements, including collaborative forest management (CFM) and forest user-group meetings. For example, Obua et al. (1998) and Kugonza et al. (2009) reported significant differences among men and women in terms of willingness to participate in forestmanagement activities. Gender imbalance between the rights and responsibilities over forest resources was cited as a major factor negatively affecting women's willingness to participate in sustainable forest management. Women normally have multiple, often, disproportionate responsibilities, and little ownership or control over productive resources. This imbalance contributes to women's subordinate and disempowered position relative to men.

Often both men and women have contrasting perceptions, priorities and goals in respect to forest management and women's specific needs. Constraints are typically not addressed while making partnership agreements between communities and forest authorities (Buyinza and Naguula 2007). However, studies in India and Nepal (Agarwal 2010; Agrawal and Yadama 2004) show that women's participation in decision making at the user-group level and in forest committees had a positive impact on forest sustainability. Women's participation for example enhanced forest regeneration and reduced illegal harvesting due to improved monitoring. This is in line with Buyinza and Naguula (2007) who argue that, for the CFM approach to succeed, local people, especially women, should be stakeholders in rule and decision making. Since effective women's participation is hindered by their inability to read and speak English (due to their low education), information targeting rural women in Uganda should be in their native languages. Local programmes should include tree resource management for the benefit of grassroots populations, many of whom have low educational levels.

A review of the literature suggests that, despite the existence of good gender, legal and policy frameworks in Uganda, participation of women in forest management still lags behind. Social norms, the gendered division of labour and gendered behavioural norms, as well as gendered spaces and species, all limit women's participation in decision making and participation in forest management (Howard and Nabanoga 2007). These social norms and cultural practices constrain women's visibility, mobility and behaviour, even when they are members of informal or formal groups (Mwangi et al. 2011). This study examines the extent to which gender features in projects and programmes by government, NGOs, donors and projects, particularly those related to natural resources. The study also focuses on understanding how gender issues are approached at the community/village/user group/district level in Uganda. We hypothesise that women's participation is more likely when external agents (e.g. NGOs or government officials) actively seek their involvement in forestry (or other) programmes and empower them through training and capacity building. 


\section{Description of the study and extent of involvement of external actors}

\subsection{Description of study area}

This study was conducted in three districts of Uganda: Mpigi, Masaka and Rakai, which are part of the Lake Victoria agroecological zone (Figure 1). Altitudes of the study area range from approximately $1,100 \mathrm{~m}$ above sea level in the valleys to $1,200 \mathrm{~m}$ above sea level on the hilltops. The area receives between 1,500 $\mathrm{mm}$ and $1,800 \mathrm{~mm}$ of rainfall per year. The topography is characterised by regularly spaced, flat-topped hills. The vegetation in this agroecological zone is characterised as a tropical, moist evergreen forest/savanna mosaic (Barbour et al. 1987; Howard 1991). Hillsides were once covered with forests, but are now dominated by a banana-coffee-fruit tree matrix (Vogt et al. 2006). The vegetation in the area is further differentiated by topographic relief (or soil drainage), which differentiates soil types. The seasonally inundated valleys support forests; the broad, permanently inundated valleys support papyrus swamps; and the hilltops support short-grassed savanna (Vogt et al. 2006).

Several property-rights regimes exist in the study area. There are many central and local forest reserves in addition to private and communal/sacred forests

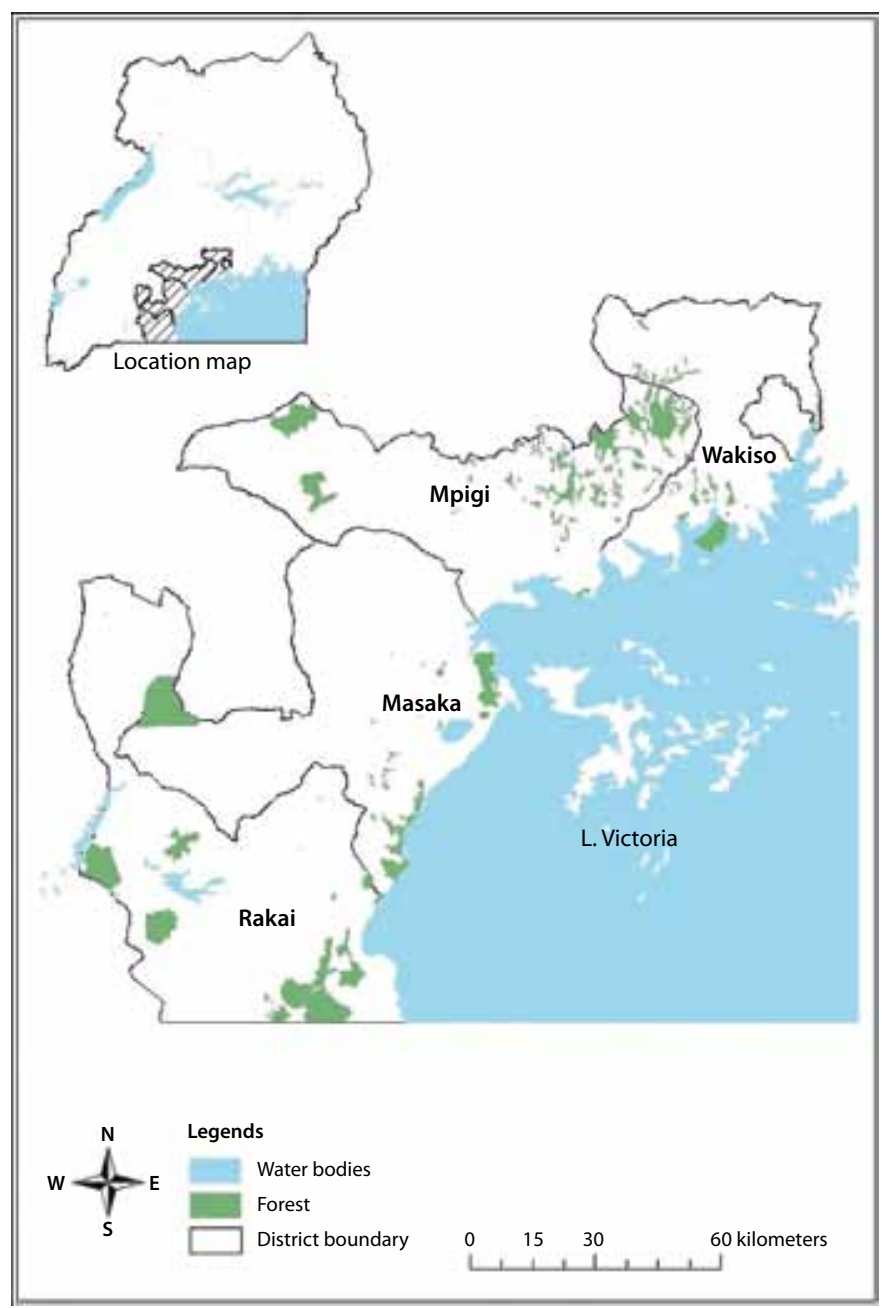

Figure 1. Lake Victoria Crescent covering the study districts of Mpigi, Masaka and Rakai 
in the Lake Victoria crescent. Past and current studies have found degradation of forestry resources to occur in all property-rights regimes (Banana and Ssembajjwe 2000). In a spatial mapping of the inter-conversions between forest and non-forest land cover classes using satellite imagery, Waiswa et al. (2011) reveal predominant conversions from forest to non-forest land cover (deforestation); conversions from non-forest to forest land cover (afforestation and/or reforestation) were also present in the area. An overlay of all the conversion maps on both the 2002 land-cover classification map and the county administrative-boundaries map of the study area revealed that deforestation mostly affected the Masaka and Mpigi parts of the Lake Victoria crescent compared to Rakai.

Several forces drive deforestation in the study area. These include weak forest governance institutions, high demand for forest produce (due to increasing population) and poor implementation of government policies in the environment sector (Banana et al. 2010). Population density in the Lake Victoria agroecological zone is high relative to the remainder of the country. Average rural population density in the 2002 census was 220 persons $/ \mathrm{km}^{2}$, significantly higher than the national average of 126 persons $/ \mathrm{km}^{2}$ (UBOS 2002). The rate has been increasing by 3.6\% per year since then.

In addition to the high population pressure, there has been a high demand for construction timber and commercial fuelwood (e.g. charcoal, brick burning and commercial baking needs) from urban centres around the lake shore over the last two decades. Exorbitant costs of electricity and paraffin encourage continued use of charcoal and fuelwood for domestic and industrial energy needs in urban areas (Republic of Uganda 2000). Kampala and other urban centres in Mpigi, Masaka and Rakai are rapidly growing in response to economic opportunities, thereby increasing the demand for timber and biomass fuels and leading to encroachment and illegal harvesting of forest produce such as timber, charcoal and firewood.

The Lake Victoria agroecological zone has also experienced rapid economic growth fueled by the Uganda government's ambitious programme of economic liberalisation (Reinikka and Collier 2001). Recent improvements in the extent and quality of road conditions in the study area make the urban centres more readily accessible to rural populations, and conversely, rural forest resources in the study area readily accessible to urban entrepreneurs (Vogt et al. 2006).

Economic liberalisation has also led to improvement in prices for agricultural crops. Most of the population in the study area practise agroforestry subsistence-farming systems. The land holdings are small, often less than 2 ha. Farmers grow a mix of crops, including perennial (banana and coffee) and annual (maize, beans, vegetables, etc.) crops, trees (e.g. Artocarpus heterophylus, Mangifera indica, Ficus natalensis, Eucalyptus) and fodder grasses (e.g. Pennisetum pupureum). Due to the small land-holdings, encroachments on forest land for production of horticultural crops or conversion of private forest land to more profitable agricultural production occur frequently in the region (Namaalwa et al. 2001).

\subsection{Criteria for selecting study districts and sites}

The three districts of Mpigi, Masaka and Rakai have many forests under private-, governmentand communal-tenure regimes. In addition, these districts represent a range of settings with regard to the extent of involvement of external actors (NGOs and government) in empowering local communities' participation in forest management. Rakai district, located $180 \mathrm{~km}$ from Kampala, the national capital, is the most remote. But it has many NGOs that have been actively empowering communities in natural resources management for the last 20 years because of the high prevalence of HIV/AIDS in this district. Mpigi is located $30 \mathrm{~km}$ from Kampala and, because of its proximity to the capital, has many government projects aimed at empowering communities. Masaka district is located about $100 \mathrm{~km}$ from Kampala and therefore has less external influence.

In the three districts, there are also a number of sites established by the Uganda Forestry Resources and Institutions Centre (UFRIC) since 1993. They follow the protocols of the International Forestry Resources and Institutions (IFRI) research programme (Ostrom 1998), which has examined relationships among local forest institutions, forest conditions and rural livelihoods for the last two decades (Banana et al. 2007). 


\section{Methodology}

\subsection{Assessing the extent to which gender features in projects and programmes}

To explore the extent to which gender features in projects and programmes, we conducted key informant interviews with personnel in organisations in the forest and natural resources sector. National organisations studied included the National Forest Authority (NFA), Forest Sector Support Department (FSSD), National Forestry Resources Research Institute, Ministry of Water and Environment (MWE), Ministry of Gender, Faculty of Forestry and Nature Conservation, Makerere University, Ndejje University and Nyabyeya Forestry College. Interviews were also conducted with personnel of local government, local and international NGOs and development agencies that had past and or current forest projects. After an initial situation analysis/ institutional mapping, respondents/NGOs were selected using a snowball sampling technique. The following key questions were asked:

1. Does your entity/organisation have a written gender policy that affirms a commitment to gender equity?

2. What are the main obstacles, in your experience, to women's participation in forest management in Uganda?

3. Would your organisation need any organisational reforms for implementing a gender perspective?

4. Do your project implementation strategies and plans take into account existing gender roles and interests of both male and female participants?

\subsection{Assessing the extent to which gender features in forest use and management in forest-adjacent communities}

To explore men's and women's notions of participation and tenure/rights and to understand the conditions that encourage/discourage participation of men and women in decision making at the community level, we conducted focus group interviews with forest user-groups, members of forest associations and local communities in the districts of Mpigi, Masaka and Rakai. User groups were selected from different forest property regimes, i.e. private forests, community forests and state forests that are available in the site/district chosen. In all, 18 study sites were selected. See Appendix 1 for site-selection criteria and name of community/user-groups studied.

Interviews and focus group discussions were conducted in Luganda (the local language) in an informal setting. The researchers who facilitated the discussions were from the same ethnic group (Baganda ethnic group). Female researchers facilitated the women focus group discussions, while male researchers facilitated the men's groups.

The following key questions were asked in the focus group interviews:

1. What kinds of activities in relation to the forest do men and women of this user group/ community do?

2. What kinds of benefits do you as a man/woman draw from being in this user group? Are you satisfied with this distribution?

3. Do you regularly hold meetings to discuss forestmanagement activities? Do women participate freely in these meetings?

4. Does this user group/community have links with other actors such as forestry officials, NGOs, politicians, local councils or researchers who assist you in making decisions related to forest management?

5. What do you understand by the terms 'rights and participation'?

\subsection{Exploring the extent to which gender features in local councils/ committees in the study districts}

Interviews were conducted at the district and subcounty level in Mpigi, Masaka and Rakai districts with elected councillors who sit on the production committees. Interviews were also held with the technical staff in charge of the directorate of natural resources who sit on the production committee as 
unofficial members. The production committees have the mandate to develop policies and oversee programmes at the district level in forestry, environment, veterinary, lands, agriculture, fisheries, marketing, finance and National Agricultural Advisory Services (NAADS), as well as gender and community development. A total of six technical persons (two from each district) were purposively selected. Three sub-counties were randomly selected from each district, making a total of nine sub-counties for the study. A list of names of 70 councillors of the production committees from the selected sub-counties was generated. Another list of names of 30 councillors from the production committees of the three district councils was also generated, making a total population of 100 councillors. From this list, 20 councillors (20\% of the study population) were randomly selected as respondents making a total of 26 respondents ( 6 exofficials and 20 elected councillors - 16 males and 10 females).

Interviews for councillors were conducted privately in English at the home or office of the respondent.
Women councillors were interviewed by a female researcher, while male councillors were interviewed by a male researcher. The interviews were intended to determine how individuals gain access to these decision making forums and their relative abilities to influence agendas and advance their goals.

The following key questions were asked in the individual interviews:

1. What kinds of decisions are made during these meetings, especially in relation to forest use and management?

2. How often have local communities channelled issues, questions or complaints to the committee?

3. How often have women channelled issues, questions or complaints to the committee?

\subsection{Data Analysis}

We coded and analysed data using the SPSS computer programme, generated statistics and presented them in table formats and summarised qualitative information to enrich the statistical data obtained. 


\section{Results}

Following the forest governance reforms, the National Forestry and Tree Planting Act 2003 promotes the participation of various stakeholders in the management of forest resources in the country. Communities participate in the management of forest reserves through the collaborative forest management (CFM) scheme with the National Forest Authority (NFA) and District Forest Services (DFS); this is in addition to the management of on-farm trees and forests on private and customary land. NGOs and CBOs build capacity in local communities to enhance their ability to participate in forest management. They also provide funds for the advocacy of sound forestry and environmental management through the media and outreach campaigns, information-sharing and networking between local communities and other forestry actors. The majority of the NGOs and CBOs are not specifically involved in forestry but are also active in other sectors such as agriculture, health and education for rural development. NFA and DFS are forest-specific government institutions that replaced the Forest Department following the enactment of the National Forestry and Tree Planting Act 2003.

\subsection{Extent to which gender features in organisational projects and programmes not specifically involved in forestry}

The primary purpose of most organisations surveyed was not specifically in forestry, but rather to work with communities to improve food security through better soil and water conservation practices and improved energy technologies. Others were involved in improving marketing of farm products and value addition of agricultural produce and on-farm trees, as well as improving livelihoods through developing alternative sources of income such as beekeeping or arts and crafts.

The majority (75\%) of the organisations had a written gender policy and a mandate to integrate gender, while about $45 \%$ had clear goals and objectives to enhance women's participation in natural resource management. The activities carried out to enhance women's participation involved strengthening women's/girls' skills through training; giving scholarships to girls; promoting affirmative action in favour of women and girls; and providing funds through microfinance institutions to women and women's groups (Table 1).

Several organisations analysed gender roles and responsibilities in the communities within which they work to take into account gender needs and disparities while implementing project activities and programmes. About $45 \%$ of organisations studied had to include gender equity as one of the objectives before proposals could be approved and funded by donors.

Despite efforts to enhance gender in project activities, less than one-third of organisations reported success (Table 2) in integrating gender. Reported success included increases in the following:

- Access of women to scholarships.

- Women's economic empowerment.

Table 1. Extent to which gender features in organisational projects and programmes not specifically involved in forestry

\begin{tabular}{|c|c|}
\hline Description & $\%$ Response $\mathrm{n}=20$ \\
\hline $\begin{array}{l}\text { Organisation has a written gender } \\
\text { policy }\end{array}$ & 75 \\
\hline $\begin{array}{l}\text { Organisations with a mandate to } \\
\text { integrate gender }\end{array}$ & 55 \\
\hline $\begin{array}{l}\text { Organisations with gender goals } \\
\text { and objectives }\end{array}$ & 45 \\
\hline $\begin{array}{l}\text { Organisations that analyse } \\
\text { gender roles and responsibilities } \\
\text { in the targeted community }\end{array}$ & 45 \\
\hline $\begin{array}{l}\text { Organisations that carry out } \\
\text { activities that strengthen } \\
\text { women's/girls' skills and provide } \\
\text { men/boys with equal access to } \\
\text { services and training }\end{array}$ & 55 \\
\hline $\begin{array}{l}\text { Organisations whose proposals } \\
\text { must include gender questions } \\
\text { before funding }\end{array}$ & 45 \\
\hline
\end{tabular}


Table 2. Perceived success stories by organisations studied

\begin{tabular}{ll}
\hline $\begin{array}{l}\text { Organisational perceived } \\
\text { success }\end{array}$ & \% Response $\mathbf{n = 2 0}$ \\
\hline $\begin{array}{l}\text { Economic empowerment of } \\
\text { women }\end{array}$ & 30 \\
$\begin{array}{l}\text { Increased capacity building- } \\
\text { scholarships to women }\end{array}$ & 25 \\
Tree planting by communities & 20 \\
$\begin{array}{l}\text { Increased participation of women } \\
\text { in community projects }\end{array}$ & 15 \\
$\begin{array}{l}\text { Prevention of illegal forest- } \\
\text { harvesting activities }\end{array}$ & 15 \\
$\begin{array}{l}\text { Increased collaboration in natural } \\
\text { resource management with: }\end{array}$ \\
- Local governments \\
- Other NGOs \\
- Government institutions \\
- Donors \\
- International agencies
\end{tabular}

- Involvement of women in community tree planting.

- Food production.

- Participation of women in community projects unrelated to forestry.

Many organisations also perceived as a measure of success the increased collaboration of organisations that work on gender and/or natural resources following the implementation of the National Forest Policy and enactment of the Local Government Act. Most (75\%) interacted with local government to implement projects that involved local communities. The local leadership was reported to give political support to organisations involved in natural resources management.

Organisations identified two major failures: the inability of women to access forest resources to earn a living and the limited number of women in key decision making positions. Women do not obtain economic benefits and rarely participate in decision making about the use of forest resources. On the other hand, men still harvest economically important forest products such as timber and charcoal.

Lack of the necessary knowledge and skills in gender by organisational staff, understaffing in many organisations, lack of operational funds and limited interest in gender issues by the organisational leadership were cited as the major obstacles in integrating gender into organisations' programmes and activities. The survey, however, indicated there is increasing pressure from donors for organisations to include gender issues in donor-funded projects (Table 3).

More than half $(55 \%)$ of the organisations studied take gender into account during strategic planning (Table 4). Other strategies to incorporate gender into organisational activities include establishment of a

Table 3. Obstacles prohibiting organisations from addressing gender issues

\begin{tabular}{lc}
\hline $\begin{array}{l}\text { Organisational factors that impede or } \\
\text { prohibit women's participation }\end{array}$ & \% Response \\
\hline Lack of gender policy & 25 \\
Lack of funds to carry out gender & 25 \\
analysis & 20 \\
Lack of gender skills in staff & 10 \\
Lack of interest by leadership & 10 \\
Limited staff & \\
\hline
\end{tabular}

Table 4. Organisational strategies to integrate gender

\begin{tabular}{|c|c|}
\hline & $\%$ Response $n=20$ \\
\hline $\begin{array}{l}\text { Organisations that take gender } \\
\text { into account during strategic } \\
\text { planning }\end{array}$ & 55 \\
\hline $\begin{array}{l}\text { Organisations with an operational } \\
\text { plan that includes clear allocation } \\
\text { of responsibilities and time for } \\
\text { monitoring and evaluation of } \\
\text { impact of gender }\end{array}$ & 25 \\
\hline $\begin{array}{l}\text { Organisations that have a focal } \\
\text { person to integrate gender within }\end{array}$ & 35 \\
\hline $\begin{array}{l}\text { Organisations that have a focal } \\
\text { person for gender }\end{array}$ & 35 \\
\hline $\begin{array}{l}\text { Organisation's staff trained in } \\
\text { gender }\end{array}$ & 40 \\
\hline $\begin{array}{l}\text { Organisation's staff trained in } \\
\text { gender planning and analysis }\end{array}$ & 35 \\
\hline $\begin{array}{l}\text { Staff training in gender } \\
\text { systematically budgeted for }\end{array}$ & 30 \\
\hline $\begin{array}{l}\text { Organisation budget adequate to } \\
\text { support gender integration }\end{array}$ & 35 \\
\hline $\begin{array}{l}\text { Organisations that need reforms } \\
\text { to integrate gender }\end{array}$ & 40 \\
\hline
\end{tabular}


gender focal person or gender desk; and developing operational plans that include clear allocation of responsibilities and time for monitoring and evaluation of the impact of gender on the outcome of their activities. However, less than $40 \%$ had a gender focal person to mainstream gender within the organisation or to train communities in gender issues. This was due to lack of skills by organisational staff.

Although most organisations studied take gender into account during strategic planning, only $25 \%$ had an operational plan to implement gender. Organisations with gender budgets conducted gender programmes such as sensitisation workshops, training and retooling staff; these included Swedish Cooperative Centre Agroforestry (SCC Vi), Integrated Rural Development Initiative (IRDI), Environmental Alert, Community Development and Conservation Agency, Association of Uganda Professional Women in Agriculture and Environment (AUPWEA) and Forum for Women in Democracy (FOWODE). We also observed that $30 \%$ of organisations systematically budgeted for training of staff in gender, gender planning and analysis (Table 4), although funds allocated were not adequate in most cases.

About $40 \%$ of organisations reported they needed internal reforms to implement a gender perspective in their activities, which could improve their success. In general, the study showed that organisations and programmes not forest-specific were aware and concerned about gender issues in the forest sector; several had strategies to increase women's participation in their activities.

\subsection{Extent to which gender features in organisational projects and programmes specifically involved in forestry}

Most forest-specific organisations surveyed were private companies involved in large- scale treeplanting projects and government agencies involved in the management of government forest reserves, both nationally and locally (Table 5). Most private companies in this category believed that local participation in forest management was not necessary and did not think that a gendered perspective in forest management would be useful or necessary. Consequently, most did not have a written policy affirming a commitment to gender equity (Table 5).
Without a gender policy, most staff in these organisations found it difficult to introduce changes to implement gender and/or community participation in forest management. The staff had no incentive to encourage women's participation since their efforts or performance could not be rated higher if they made extra efforts to involve local communities or women in forest management. Private tree growers, however, were found to provide employment to both men and women, mostly on contract. Men carried out forest-plantation management activities such as bush clearing, planting, pruning, thinning and felling trees, while women provided labour to produce seedlings. With limited skills in forest plantations and lack of tenure, most local communities were found not to participate in decision making in forest plantation management. Increasingly, private forest companies and key forest players are working with surrounding communities by giving them employment, free seedlings and training as their corporate social responsibility.

Local communities, and especially women, could not participate in large-scale tree planting because of:

- Lack of capital to plant a minimum of 5 ha required by the donors under the Sawlog Production Grant Scheme (SPGS) before one could access funding.

- A long rotation period to grow trees for timber.

- Eucalyptus and pine tree species not being the preferred species of women or other community members.

- Most forest land adjacent to communities was allocated to large private investors such as New Forest Company and Green Resources Norway under the SPGS and to the National Forest Authority (NFA).

On the other hand, government organisations and programmes such as the NFA and District Forest Services (DFS) explored involving local communities and especially women in forest management through CFM arrangements.

These organisations have a legal mandate to mainstream gender in their activities; they understand participation as a process of involving local communities in the management of forest patches adjacent to settlements under CFM arrangements. The communities, under CFM 
Table 5. Projects/organisations specifically involved in forestry and tree planting

\begin{tabular}{|c|c|c|c|}
\hline Name of organisation/project & $\begin{array}{l}\text { Gender } \\
\text { policy }\end{array}$ & $\begin{array}{c}\text { Existence of } \\
\text { strategies to } \\
\text { implement } \\
\text { policy }\end{array}$ & Factors hindering women's participation \\
\hline \multirow[t]{2}{*}{$\begin{array}{l}\text { Uganda Timber Growers } \\
\text { Association (UTGA) }\end{array}$} & $\mathrm{N}$ & Y & $\begin{array}{l}\text { Large-scale commercial tree planting that excludes } \\
\text { women due to lack of capital }\end{array}$ \\
\hline & & & $\begin{array}{l}\text { Promotes only timber tree species which are less attractive } \\
\text { to women }\end{array}$ \\
\hline \multirow[t]{2}{*}{$\begin{array}{l}\text { Sawlog Production Grant } \\
\text { Scheme (SPGS) }\end{array}$} & $\mathrm{N}$ & $\mathrm{Y}$ & $\begin{array}{l}\text { Large-scale commercial tree planting, which excludes } \\
\text { women due to lack of capital }\end{array}$ \\
\hline & & & $\begin{array}{l}\text { Promotes only timber tree species, which are less } \\
\text { attractive to women }\end{array}$ \\
\hline \multirow[t]{3}{*}{ National Forest Authority (NFA) } & Y & Y & Few trained women foresters \\
\hline & & & $\begin{array}{l}\text { Strenuous nature of some activities, including patrolling; } \\
\text { more women are employed in NFA nursery activities }\end{array}$ \\
\hline & & & $\begin{array}{l}\text { Fear of danger when confronting persons doing illegal } \\
\text { activities in the forest }\end{array}$ \\
\hline \multirow[t]{3}{*}{ District Forest Service } & $?$ & Y & Few trained women foresters \\
\hline & & & $\begin{array}{l}\text { Strenuous nature of some activities, including patrolling; } \\
\text { more women are employed in NFA nursery activities }\end{array}$ \\
\hline & & & $\begin{array}{l}\text { Fear of danger when confronting persons doing illegal } \\
\text { activities in the forest }\end{array}$ \\
\hline $\begin{array}{l}\text { National Forestry Resources } \\
\text { Research Institute (NaFORRI) }\end{array}$ & $\mathrm{N}$ & $\mathrm{N}$ & Few trained women foresters and researchers \\
\hline $\begin{array}{l}\text { Budongo community Forest } \\
\text { Conservation project (BCFCP) }\end{array}$ & $\mathrm{N}$ & $\mathrm{N}$ & Strenuous nature of some activities including patrolling \\
\hline \multirow{3}{*}{$\begin{array}{l}\text { Farm Income Enhancement } \\
\text { and Forest Conservation } \\
\text { (FIEFOC) }\end{array}$} & $?$ & Y & Disparities in land and tree ownership, marriage insecurity \\
\hline & & & $\begin{array}{l}\text { Few tree species meeting women's needs and interests } \\
\text { (fuel wood, food and nutritional security, soil fertility } \\
\text { improvement and water conservation) }\end{array}$ \\
\hline & & & $\begin{array}{l}\text { Fewer women field officers working with communities } \\
\text { compared to men }\end{array}$ \\
\hline \multirow[t]{3}{*}{ New Forest Company } & $\mathrm{N}$ & $?$ & Many women employed in nursery activities and fewer or \\
\hline & & $\mathrm{N} ?$ & none in strenuous forest activities \\
\hline & & $Y ?$ & Few women trained in plantation forestry \\
\hline \multirow[t]{2}{*}{ Core woods } & $\mathrm{N}$ & $\mathrm{N}$ & $\begin{array}{l}\text { Many women employed in nursery activities and fewer or } \\
\text { none in strenuous forest activities }\end{array}$ \\
\hline & & & Few women trained in plantation forestry \\
\hline \multirow[t]{2}{*}{ Green Resources Norway } & $\mathrm{N}$ & $?$ & $\begin{array}{l}\text { Many women employed in nursery activities and fewer or } \\
\text { none in strenuous forest activities }\end{array}$ \\
\hline & & & Few women trained in plantation forestry \\
\hline
\end{tabular}

agreements with NFA or DFS, can decide who is authorised to harvest, when they can harvest and how much they can harvest from the forest patch managed by the community. Communities patrol forest boundaries and undertake various silvicultural activities under the guidance of NFA or DFS.
Organisations involved in the management of natural forests have found several factors influence community participation:

- Limited benefits accruing to participating communities. 
- The desire by communities to convert forest land to agriculture due to scarcity of land.

- Insecure forest- and tree-security whereby communities are not sure they will be allowed to harvest the trees in future.

The following factors were found to influence women's participation in collaborative forest management:

- Strenuous nature of field-forestry activities, including patrolling.

- Fear of danger when confronting persons doing illegal activities in the forest.

- Limited economic benefits accruing to participating women.

- $\quad$ Long distances from homesteads.

Only one government initiative, the Farm Income Enhancement and Forest Conservation project (FIEFOC), supports communities and private individuals. The project objective is to alleviate rural poverty in 33 districts of Uganda through planting trees on-farm and in woodlots. Its goal is to plant 13 500 ha of forest, which is expected to produce poles and fuelwood of about $472500 \mathrm{MT}$ and $94500 \mathrm{MT}$, respectively. FIEFOC has a gender-mainstreaming manual that highlights gender issues to be addressed in planning and implementation of project activities. The project encourages its staff to take on issues related to involvement of women in on-farm tree planting, such as conducting gender capacitybuilding workshops in communities.

Although the FIEFOC project targets equal participation of men and women, in practice, there are always fewer female applicants (average 30\%). The lack of female participants in on-farm tree planting initiatives is mainly attributed to gender disparities in land ownership, cultural norms and practices, heavy domestic work loads and provision of seedlings of tree species not preferred by women (mainly timber and pole species are offered, while women prefer fruit and fuelwood species).

Individuals interviewed in organisations specifically involved in forestry suggested that organisational reforms were needed to improve community participation in forest management. The suggested reforms include:

- Providing incentives to staff to engage in capacity building of local communities.
- Creating awareness among staff, especially the leadership, about the role communities can play in enhancing sustainable forest management.

- Providing information to local communities in local languages.

- Increasing networking of organisations that encourage local community participation.

In general, although some government forestry agencies were aware of the legal requirement to integrate gender, gender issues do not feature prominently in organisational projects and programmes specifically involved in forestry. The major obstacles for integrating gender in forestspecific organisations and programmes include inadequate budgets for gender mainstreaming coupled with limited staff training in gender issues.

\subsection{Extent to which gender features in forest communities}

The purpose of interviewing forest user-groups was to:

- Understand men's and women's notions of participation and tenure/rights.

- Examine conditions that encourage/discourage participation of men and women.

- Understand decision making processes in forest user-groups and forest communities, including the kinds of decisions made, how they are made and who tends to influence decision making.

Following the implementation of governance reforms in 2001, some forest adjacent communities formed forest associations to enhance rural livelihoods while using forest resources sustainably. In the following sub-section, we analyse the role of gender in formal forest-associations.

\subsubsection{Extent to which gender features in formal forest-associations}

The primary purposes of most associations include:

- Conservation of forest resources using collaborative forest management agreements with the NFA.

- Afforestation and reforestation of degraded communal and local government forests.

- On-farm and commercial tree planting. 
Other non-forestry activities in which the associations were involved include:

- Sustainable land-use management (soil and water conservation) for improved food security.

- Beekeeping.

- Energy conservation such as promotion of improved cook stoves.

In this study, more than two-thirds of the formal registered forest-associations were involved in CFM arrangements. Associations adjacent to private forests were involved in on-farm and commercial tree planting, while those adjacent to communal and heavily degraded local forest-reserves were engaged in afforestation and reforestation efforts.

All the associations found in the study sites are mixed user-groups. Only two associations had more women than men members (Table 6). The leadership of these associations was also dominated by men; we found only two associations led by women. About $75 \%$ of the associations studied reported an increase in membership of both men and women in recent times, while $25 \%$ reported a decline in membership. The decline was due to expulsion of members who fail to pay membership fees.

All the associations in the study reported having linkages with external actors such as the National Forest Authority, district forestry officials, NGOs such as SCC Vi Eastern Africa, local councils and politicians. Most of these external actors were instrumental in the formation of these associations (Table 7): forestry officials worked with communities in the formulation of CFM agreements; NGOs were involved in capacity building, creation of awareness about the change in forest law, preparation of project documents for formal registration and fundraising, in addition to monitoring the performance of project activities; local councils and politicians were involved in community mobilisation.

The majority of the forest user-groups were satisfied with the linkage between themselves and the NGOs. For example, SCC Vi Eastern Africa was ranked by most communities and forest associations as the most influential NGO involved in tree planting and many other socioeconomic and environmental interventions. Communities were least satisfied with the linkage between themselves and local councils, forestry officials and politicians. Corruption and political interference were cited as the major reasons for the poor working-relationship with these organisations.

The members of the forest associations suggested the following ways to improve linkages with external actors:

- Increase sensitisation and capacity-building workshops for youth and women.

- Provide more tree seedlings to associations involved in tree planting.

- Enhance benefits to communities participating in CFM.

The enhanced interest of both men and women to join formal forest user-groups may be due to the benefits of membership. The following is a summary of the major benefits that accrue to various members of user-groups in the study sites in descending order:

1. Increased access to financial services (from NGOs and micro-finance institutions).

2. Better networking with other associations located within the country.

3. Increased access to resources in the forest(s).

4. Better technical support (capacity building) in various aspects of natural resource management such as beekeeping, soil fertility management, water conservation, tree establishment, management of small-scale enterprises and food security.

5. Enhanced household income and food security due to increased access to high-quality planting materials of both trees and crops.

6. Access of associations to government forest land for commercial tree planting.

7. Increased employment opportunities in forestbased enterprises such as patrolling of forest boundaries.

Most user groups reported equitable sharing of most benefits between women and men. Both men and women have equal access to technical and financial support from NGOs and financial institutions, most preferably as an association. Both men and women have equal chance of networking with other user groups. However, it was reported that men have better employment opportunities in the forest-based activities formed by the groups. 
Table 6. Formal user-groups studied

\begin{tabular}{|c|c|c|c|c|}
\hline Name & Forest and tenure & Age of group (years) & Activities & Gender composition \\
\hline $\begin{array}{l}\text { Ndugu Beekeeping } \\
\text { and Farmers' Group }\end{array}$ & $\begin{array}{l}\text { Mpanga } \\
\text { Government CFR }\end{array}$ & 5 & $\begin{array}{l}\text { Conservation of } \\
\text { forest resources; } \\
\text { income and food } \\
\text { security }\end{array}$ & $\begin{array}{l}\text { Men }=25 \\
\text { Female }=17\end{array}$ \\
\hline $\begin{array}{l}\text { Bukeri Tree Planting } \\
\text { Association }\end{array}$ & $\begin{array}{l}\text { Nabuzaale Catholic } \\
\text { Church Forest } \\
\text { Nabukonge CFR }\end{array}$ & 8 & $\begin{array}{l}\text { Afforestation for } \\
\text { poverty reduction }\end{array}$ & $\begin{array}{l}\text { Men }=34 \\
\text { Female }=22\end{array}$ \\
\hline $\begin{array}{l}\text { Kizira Coffee Farmers' } \\
\text { Association }\end{array}$ & Private Forest & 6 & $\begin{array}{l}\text { Promotion of farm } \\
\text { forestry and coffee } \\
\text { production }\end{array}$ & $\begin{array}{l}\text { Men }=17 \\
\text { Female=8 }\end{array}$ \\
\hline $\begin{array}{l}\text { Kwekulakulanya Tree } \\
\text { Planting Project }\end{array}$ & $\begin{array}{l}\text { Kamuswaga } \\
\text { Communal Forest }\end{array}$ & 5 & $\begin{array}{l}\text { Sustainable land-use } \\
\text { management }\end{array}$ & $\begin{array}{l}\text { Men }=16 \\
\text { Female }=14\end{array}$ \\
\hline $\begin{array}{l}\text { Kigazi } \\
\text { Tukwatirewamu } \\
\text { Forest Group (2001) }\end{array}$ & Sango Bay CFR & 10 & $\begin{array}{l}\text { Promotion of nature } \\
\text { conservation through } \\
\text { tree planting and } \\
\text { CFM }\end{array}$ & $\begin{array}{l}\text { Men }=32 \\
\text { Female }=44\end{array}$ \\
\hline $\begin{array}{l}\text { Mugamba- } \\
\text { Mujanjabula Save the } \\
\text { Forest Group }\end{array}$ & Sango Bay CFR & 5 & $\begin{array}{l}\text { Forest conservation } \\
\text { through CFM } \\
\text { and livelihood } \\
\text { improvement }\end{array}$ & $\begin{array}{l}\text { Men }=59 \\
\text { Female }=68\end{array}$ \\
\hline $\begin{array}{l}\text { Nalubega } \\
\text { Mutegomba } \\
\text { Community Forest }\end{array}$ & $\begin{array}{l}\text { Namala CFR \& } \\
\text { Mutegomba } \\
\text { Community Forest }\end{array}$ & 4 & $\begin{array}{l}\text { Nature conservation } \\
\text { and tree planting }\end{array}$ & $\begin{array}{l}\text { Men=45 } \\
\text { Female =35 }\end{array}$ \\
\hline $\begin{array}{l}\text { Nabukonge } \\
\text { Community Tree } \\
\text { Planting }\end{array}$ & $\begin{array}{l}\text { Nabukonge CFR } \\
\text { and Catholic Church } \\
\text { Forest }\end{array}$ & 5 & $\begin{array}{l}\text { Commercial tree } \\
\text { farming }\end{array}$ & $\begin{array}{l}\text { Men }=65 \\
\text { Female }=50\end{array}$ \\
\hline
\end{tabular}

Table 7. Benefits that accrue to members in registered forest-user groups

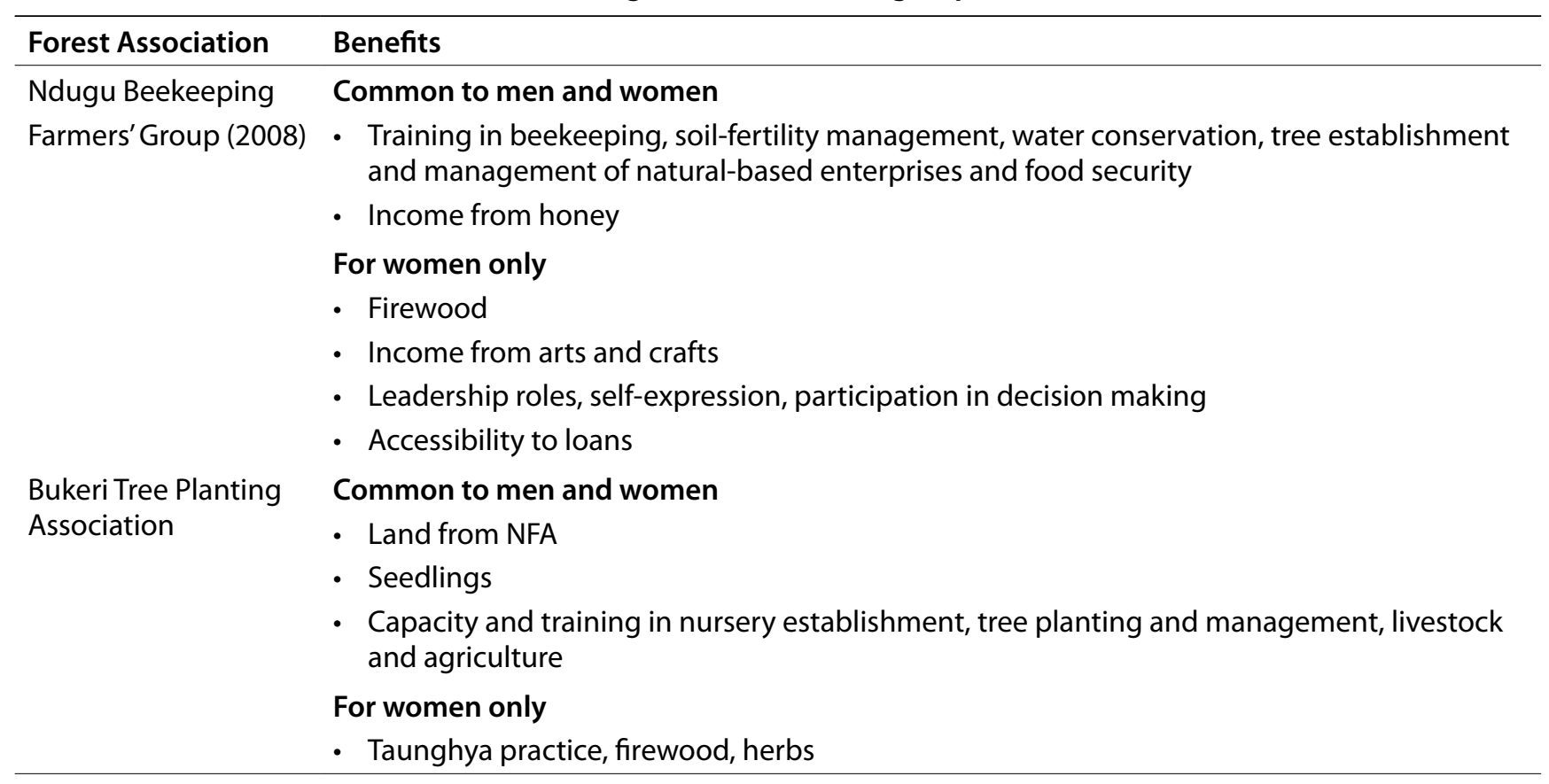


Table 7. Continued

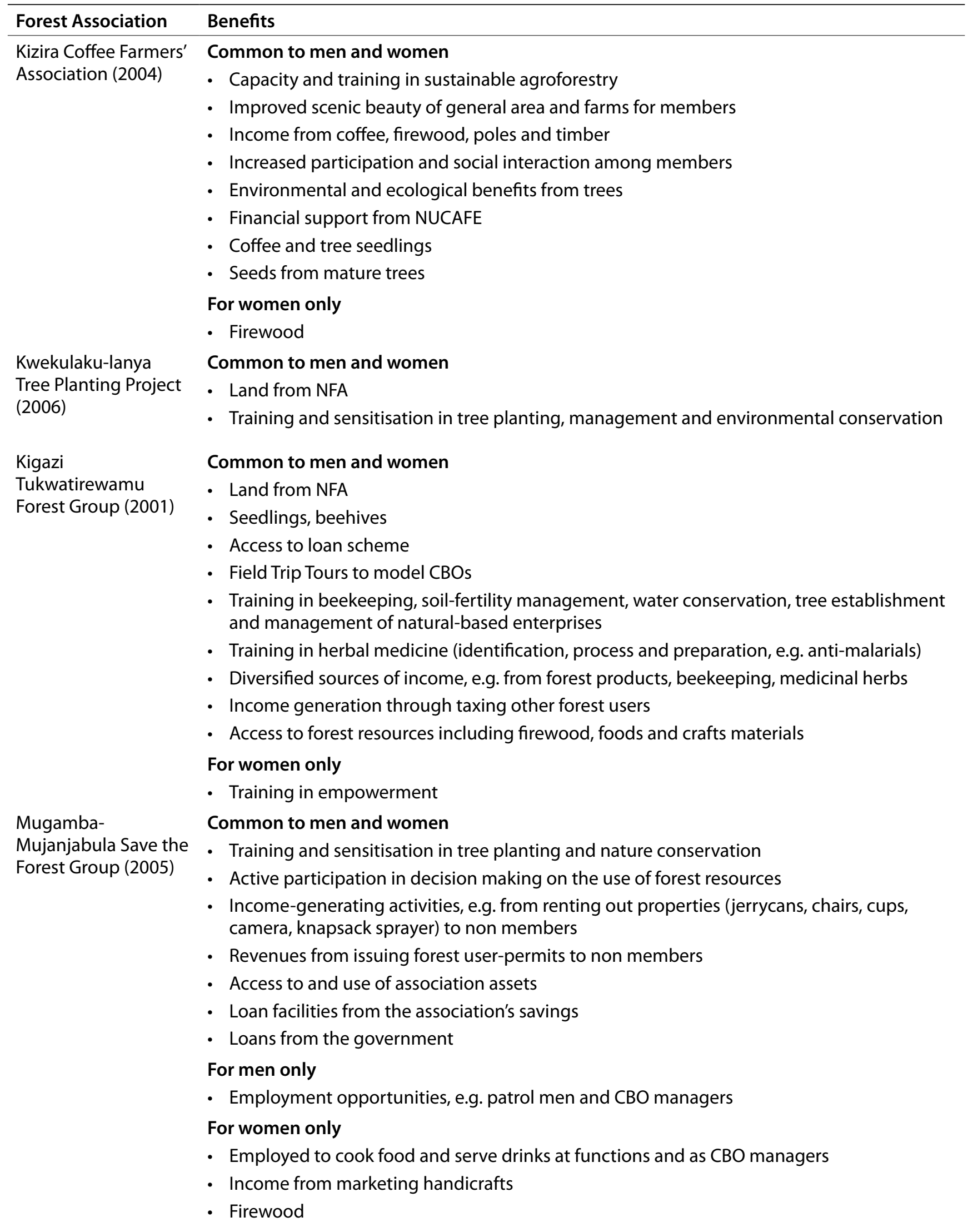


Table 7. Continued

\begin{tabular}{ll}
\hline Forest Association & Benefits \\
\hline $\begin{array}{l}\text { Nalubega } \\
\text { Community Forest }\end{array}$ & Common to men and women \\
$(2007)$ & - Demonstrated interest in forestry conservation and tree planting \\
& For men only \\
& - Access to better quality seedlings \\
& For women only \\
& - Seedlings, \\
& - Training in energy conservation and making energy-saving stoves \\
& - Firewood \\
& - Incomes from arts and crafts \\
Commoss to land through Taunghya practice \\
Planting (2006)
\end{tabular}

The study examined activities carried out by both men and women in the forest associations. While most activities were carried out by men and women together, various associations reported several gender specific activities. The following are the activities mainly carried out by men, starting with the highest ranked:

1. Planting of commercial timber trees on-farm.

2. Patrolling and protecting forests against fires.

3. Clearing land for woodlot or plantation establishment.

4. Pruning, thinning and other silvicultural activities.

5. Processing and marketing of wood products.

6. Fishing - in forests that have rivers and swamps.

The following are the activities mainly carried out by women, starting with the highest ranked:

1. Planting fruit and firewood trees on-farm.

2. Extracting materials for use in handicraft production.

3. Watering seedlings during the dry period and other seedling nursery work.

4. Selling crafts, fruits and firewood from on-farm trees.

5. Preparing meals for members when the group is carrying out intensive field work.
About half of the associations believed they were successful in carrying out the above activities.

Consequently, they continued to receive support from partner organisations. Several associations have been able to acquire land from the government for tree planting and many households have diversified their income-generating activities.

More than $40 \%$ of the associations believed they were not very successful in carrying out their activities. They attributed the limited success to the following, starting with the highest ranked:

1. Mismanagement of association funds.

2. Inadequate training and sensitisation of members.

3. Limited access to forestry resources due to restrictions imposed by either group members or forestry officials.

4. Highly degraded forestry resources allocated to the association to manage.

5. Unclear land- and tree-tenure issues.

6. Poor working relationship with forestry officials.

Members of the associations suggested taking the following measures to improve group success in forest-management activities, starting with the highest ranked:

1. Continued community training and sensitisation by NGOs and government officials. 
Table 8. Roles carried out by men and women

\begin{tabular}{|c|c|c|}
\hline \multirow[t]{2}{*}{ Name of Association } & \multicolumn{2}{|c|}{ Roles } \\
\hline & Men ( $\&$ male children) & Women ( \& children) \\
\hline $\begin{array}{l}\text { Ndugu Beekeeping } \\
\text { and Farmers' Group } \\
\text { (2008) }\end{array}$ & $\begin{array}{l}\text { - On-farm planting of commercial trees for } \\
\text { timber, poles and drum making } \\
\text { - Acquiring and locating beehives } \\
\text { - Harvesting and marketing honey }\end{array}$ & $\begin{array}{l}\text { - On-farm planting of fruit and medicinal, trees, } \\
\text { - On-farm selling of fruits } \\
\text { - Honey processing } \\
\text { - Extracting crafts materials, making and } \\
\text { selling arts and crafts }\end{array}$ \\
\hline $\begin{array}{l}\text { Bukeri Tree Planting } \\
\text { Association }\end{array}$ & $\begin{array}{l}\text { - Land clearing, lining, pitting, patrol } \\
\text { - Slashing, pruning, thinning }\end{array}$ & $\begin{array}{l}\text { - Carrying seedlings to planting sites, planting, } \\
\text { weeding } \\
\text { - Preparing meals for group members while } \\
\text { working } \\
\text { - Nursery activities }\end{array}$ \\
\hline $\begin{array}{l}\text { Kizira Coffee Farmers' } \\
\text { Association (2004) }\end{array}$ & $\begin{array}{l}\text { - Group coffee-selling to Nucafe } \\
\text { - Seed collection and tree seedling nursery } \\
\text { activities } \\
\text { - Land preparation, planting trees for different } \\
\text { purposes, weeding } \\
\text { - Pruning, thinning, harvesting tree products } \\
\text { - Marketing and sale of wood products }\end{array}$ & $\begin{array}{l}\text { - Group coffee-selling to Nucafe } \\
\text { - Seed collection and tree seedling nursery } \\
\text { activities } \\
\text { - Land preparation, planting trees for different } \\
\text { purposes, weeding } \\
\text { - On-farm selling of forest firewood and fruits }\end{array}$ \\
\hline $\begin{array}{l}\text { Kwekulakulanya } \\
\text { Tree Planting Project } \\
\text { (2006) }\end{array}$ & $\begin{array}{l}\text { - Land clearing, lining, pitting patrol and } \\
\text { protection from stray animals and grazers } \\
\text { - Slashing, pruning, thinning, fire fighting }\end{array}$ & $\begin{array}{l}\text { - Carrying seedlings to planting sites, planting, } \\
\text { watering young plants during dry season, } \\
\text { weeding }\end{array}$ \\
\hline $\begin{array}{l}\text { Kigazi } \\
\text { Tukwatirewamu } \\
\text { Forest Group (2001) }\end{array}$ & $\begin{array}{l}\text { - Land clearing, lining, pitting, patrol the } \\
\text { plantation and Maramagambo (Sango Bay) } \\
\text { CFR } \\
\text { - Slashing, pruning, thinning, fire control } \\
\text { - Issuance of forest user-permits (UGX 1,000) to } \\
\text { non members and revenue collection } \\
\text { - Paying UGX 1,500 monthly for running the } \\
\text { loan scheme } \\
\text { - Beekeeping activities } \\
\text { - Fishing }\end{array}$ & $\begin{array}{l}\text { - Carrying seedlings to planting sites, planting, } \\
\text { weeding } \\
\text { - Issuance of forest-user permits to non } \\
\text { members and revenue collection } \\
\text { - Paying UGX } 1,500 \text { monthly for running the } \\
\text { loan scheme } \\
\text { - Beekeeping activities }\end{array}$ \\
\hline $\begin{array}{l}\text { Mugamba- } \\
\text { Mujanjabula Save the } \\
\text { Forest Group (2005) }\end{array}$ & $\begin{array}{l}\text { - Issuance of forest-user permits (UGX 3,000) to } \\
\text { non members and revenue collection } \\
\text { - Clearing land, lining, pitting } \\
\text { - Patrolling the plantation and Sango Bay CFR } \\
\text { - Running association enterprises (loan } \\
\text { scheme, renting out properties) } \\
\text { - Slashing, pruning, thinning, fire fighting, } \\
\text { weed control through chemical spraying, } \\
\text { protecting young plants from grazers } \\
\text { - Fishing }\end{array}$ & $\begin{array}{l}\text { - Issuance of forest-user permits to non } \\
\text { members and revenue collection } \\
\text { - Carrying seedlings to planting sites, planting, } \\
\text { weeding } \\
\text { - Running association enterprises (loan } \\
\text { scheme, renting out properties) }\end{array}$ \\
\hline $\begin{array}{l}\text { Nalubega } \\
\text { Mutegomba } \\
\text { Community Forest } \\
\text { (2007) }\end{array}$ & $\begin{array}{l}\text { - Clearing land, lining, pitting, planting } \\
\text { - Patrolling the plantation and Sango Bay CFR } \\
\text { - Slashing, pruning, thinning } \\
\text { - Fishing }\end{array}$ & $\begin{array}{l}\text { - Carrying seedlings to planting sites, planting, } \\
\text { weeding } \\
\text { - Harvesting NTFPs and making arts and crafts } \\
\text { (e.g. mats and baskets) }\end{array}$ \\
\hline $\begin{array}{l}\text { Nabukonge } \\
\text { Community Tree } \\
\text { Planting (2006) }\end{array}$ & $\begin{array}{l}\text { - Clearing land, lining, pitting, planting, } \\
\text { - Patrolling, slashing, pruning, thinning, } \\
\text { harvesting }\end{array}$ & $\begin{array}{l}\text { - Carrying seedlings to planting sites, planting, } \\
\text { weeding }\end{array}$ \\
\hline
\end{tabular}


2. Improved working relationship between the communities and forestry officials.

3. Intensification of agroforestry practices to reduce pressure of illegal harvesting from natural forests.

4. Better accountability of association funds.

The focus group discussion shed light on decision making within the associations, including the kind of decisions that get made, how they are made and who influences the agenda and decision making. During these discussions, we also endeavoured to understand how members understood the terms 'tenure rights to forests' and 'community participation' in forest management and whether they were aware that the Forest Act had changed to encourage more community participation.

The different associations all understood 'participation' in their own way. Most members saw it as working in a group to manage natural resources, including forest management, processing and marketing of agricultural and forest products. Others understood participation as working with forest officials and NGOs in management of forestry resources and planting of on-farm trees.

Again, the majority of the members understood the term 'rights to forest resources' differently. About $30 \%$ understood rights as entitlement that men, women and children have to forest resources. Others thought the term was similar to 'human rights' or 'freedom to do what one would like'.

Most associations held meetings regularly; about half met once a month, while the others met once every three months. The executive committee, external actors (NGOs, researchers and visitors) and sometimes community leaders were reported to set the agenda for discussion. The following are some issues discussed in the executive and/or general meetings of the associations:

- Identifying forest-management activities for the next quarter.

- Distributing roles among members.

- Regulating harvesting levels by allocating permits or monitoring and enforcing forest-produce harvesting regulations.

- Lobbying for financial and technical support.

- Using, and accounting for, association funds.
All associations in the study reported that women regularly attend association meetings, participate fully in discussions and freely express their opinions. All associations have records of attendance and keep minutes. Women often attend general meetings in high numbers probably because meetings are conducted within the settlements and do not require travelling long distances. However, most associations were headed by men except two that were dominated and headed by women.

About $30 \%$ of associations reported that association leaders, council officials (local politicians) and wealthy individuals influence and control decision making during association meetings. These individuals or sub-groups are educated and opinion leaders within their communities. They influence decision making by determining the agenda and also by dominating most of the discussions.

In conclusion, the study showed that most members of forest associations are able to take part in decision making to some extent; most of the associations have formalised decision making structures such as management councils that involve local stakeholders and meet on a regular basis.

In addition, forest-association members are able to assume primary management responsibility. Thus, according to Bina Agarwal's typologies (2001) in participatory exclusions, the level of participation of members of forest associations range from negotiation or active/functional participation (level E) through sharing of authority or interactive participation (level F) to transferring authority or taking over responsibility (level G). Forest associations have been empowered to manage forest patches and other natural resources and enterprises within their vicinity. In the next sub-section, we examine how communities without formal usergroup associations manage their forest resources.

\subsubsection{Extent to which gender features in informal forest user-groups}

In this study, 10 communities living adjacent to forests and not organised into associations were categorised as informal forest user-groups. The purpose of interviewing these communities was to:

- Understand communities' notions of participation and tenure/rights. 
- Examine conditions that encourage/discourage participation of communities (men and women).

- Understand decision making in communities, including the kinds of decisions made, how they are made and who tends to influence decision making.

Communities reported they were involved in the following forest-improvement activities, starting with the highest ranked:

1. Raising of tree seedlings for on-farm planting and enrichment planting of degraded forests (mostly women).

2. Enrichment planting of trees in degraded forest reserves.

3. On-farm tree planting.

4. Patrol of forest boundaries to control illegal harvesting of forest produce (in $15 \%$ of the communities).

Nine out of 10 communities reported limited success at rehabilitating the central forest reserves. Forest degradation still continues. Failure to improve forestry resources was attributed to poor working relationships with forestry officials because of:

- Limited involvement of the communities in decision making.

- Limited legal access to forest products (e.g. a legal document in the form of a permit is required for harvesting timber, firewood).

- Confiscation of tools and equipment from people involved in illegal activities.

- Unsustainable harvesting of timber by people from outside the community who are given official permits to harvest forest resources.

- Unwillingness of people to patrol forest boundaries with limited benefits accruing to them.

On the other hand, planting of on-farm trees, or in private and communal woodlots by both men and women, was reported to be successful in most communities. Success in this activity was attributed to:

- Strong land- and tree-tenure in the region.

- Severe shortage of forest products from the degraded natural forests, which is an incentive for people to plant on-farm trees.
- Increased household income from selling by men of poles and firewood from quick-rotation tree crops.

- Increased household income from selling of seedlings by women.

- Women's awareness of the importance of planting fruit, as well as trees for soil and water conservation.

- Technical and financial input by external actors, mainly NGOs to plant on-farm trees.

However, it was reported in one community that certain norms and myths prevent women from planting particular tree species. For instance, there is a belief that if women plant 'Mutuba' (Ficus nantalensis), their husbands may become impotent.

The following are some of the most frequent suggestions by communities to improve their participation in forest-improvement activities:

- Establishment of a better working relationship between the community and the district and NFA forest officials.

- Increased involvement of communities in decision making, especially in determining who is authorised to harvest timber.

- Reduction of fees to harvest timber.

- Increased sensitisation of communities about biodiversity conservation.

- Revitalised traditional institutions involved in forest management.

- Formation of forest-user and management associations.

- Capacity building for processing and marketing of non-timber forest products (NTFPs).

- Increased domestication of high-value tree species.

Benefits drawn by forest adjacent communities from forests and how they are distributed by gender are similar to those reported by formal forest usergroups. No member in any one community was formally employed to work in the government forest reserves. A few members (5\%) were, however, employed as labourers by private tree growers in forest plantations and woodlots. Women were employed in tree nurseries. We found eight treeseedling nurseries in the study area managed by women. About $10 \%$ of the households also benefit from the government forest reserves by practising 
apiary. Both men and women have beehives in the forest.

All communities studied (both formal and informal) reported extensive use of forest resources for both subsistence and income generation. Access to forest products was determined by forest tenure and gender (Table 9). The most important products harvested by men in all the communities studied were timber, firewood, charcoal, poles, sand and clay for sale from government forest reserves and communal forests. Men also reported hunting, grazing and fishing as major activities in several communities.

With respect to government forest reserves and communal forests, the most important products harvested by women were firewood, water and forest foods; both men and women cultivate in these forests, as well as worship and harvest medicinal herbs and craft materials; youth collect water, firewood, fruits, mushrooms and honey. Members of the forest associations (where these exist) issue permits to household members to legally harvest NTFPs (mainly fish, forest foods, and water and craft materials) from forest reserves.

Short-term encroachments for timber or charcoal harvesting, followed by planting seasonal horticultural crops such as vegetables, beans and maize, is widespread in Mpigi, Masaka and Rakai. Men grow maize, tomatoes, ginger and other vegetables as commercial crops, while women grow beans and sweet potatoes for subsistence. When forest officials evict encroachers, forest regeneration and the canopy closure is rapid, even in seasonally inundated valleys less conducive to the prevailing production system. However, most people in the focus groups denied being engaged in timber, charcoal harvesting or cultivation in forest reserves; they accused outsiders of being involved in these activities.

Most communities in the study area make handicrafts, which are sold in crafts shops located along the main Kampala-Masaka-Mbarara-Kigali highway and during community market days. Men in Mpigi and Masaka make drums and stools, while women make baskets and mats for both local and international markets.

Fishing and cattle grazing are major activities in the swamp forests and wetlands located in the forest reserve along the shores of Lake Victoria. The main fish species harvested is Nzozi (Clarias gariepinus and Clarias carsoni). Both men and boys carry out fishing and grazing in swamps during the dry season. The fish is sold in both local markets and major urban centres in the region.

In all three districts, collecting fodder for cows and pigs is also a major farming activity for women in many households. Women own one or two cows and a pair of pigs. The women harvest fodder from the forest and along the roads to feed their livestock.

In the study sites in Mpigi and Masaka, where government forest reserves are severely degraded, some individual households have established private woodlots, while others maintained private natural forests on their land. Property rights are clearly defined and enforced. Group discussions emphasised that 'it is illegal to trespass on one's land planted with trees'. Since men own the land, women have limited access to such planted forest resources. Women, however, harvest firewood after the men have harvested the trees for timber or poles.

Forest owners control access to private natural forests. The local communities have access rights to harvest water, dead branches of trees for firewood and medicinal herbs, as well as wild fruits and vegetables for subsistence use.

Access to communal forests is controlled by the village leadership, including elders, according to cultural norms of the area. These traditional institutions do not normally include women in decision making. Communal sacred forests are controlled by clan elders (which also exclude women) according to the myths and traditions of a given forest.

More than $90 \%$ of communities reported that, since the establishment of the NFA, village meetings on the use of forest resources are no longer regular. More than five years ago, village and parish production committees - where forest issues are supposed to be discussed - ceased functioning due to a failure to hold elections. Councillors who have resigned, died or migrated out of the villages have not been replaced. More than two-thirds of communities reported that they regularly meet with NGOs, Community Development Officers (CDOs), NAADS and officials of microfinance institutions 
Table 9. Forest-harvesting activities

\begin{tabular}{|c|c|c|c|}
\hline \multirow[t]{2}{*}{ Type of forest } & \multirow[t]{2}{*}{ Type of activity in the forest } & \multicolumn{2}{|r|}{ Sex } \\
\hline & & Men & $\begin{array}{l}\text { Women ( } \& \text { male and } \\
\text { female children) }\end{array}$ \\
\hline \multirow[t]{25}{*}{ CFR } & Collecting firewood for home use & & $\mathrm{Y}$ \\
\hline & Collecting water & & Y \\
\hline & Making charcoal and cutting firewood & $\mathrm{Y}$ & \\
\hline & Collecting medicinal materials & $\mathrm{Y}$ & $\mathrm{Y}$ \\
\hline & Pit-sawing (illegal and permitted) & Y & \\
\hline & Harvesting of drum-making trees (only in Ndugu, Mipigi district) & $\mathrm{Y}$ & \\
\hline & Poles & Y & \\
\hline & Hunting/trapping wild animals & Y & \\
\hline & Grazing animals & Y & \\
\hline & Arts and crafts & & \\
\hline & Marantochloa perpurea (basketry materials) & & Y \\
\hline & Phoenix reclinata (palm leaves) & Y & Y \\
\hline & Raphia farinifera (fibres for mats) & $\mathrm{Y}$ & \\
\hline & Collection of forest foods & & \\
\hline & Mushrooms & & $\mathrm{Y}$ \\
\hline & Fish & $\mathrm{Y}$ & \\
\hline & Wild fruits & & Y \\
\hline & Collection of seedlings & & \\
\hline & Coffee & Y & \\
\hline & Fruits, herbs, and other species & Y & Y \\
\hline & Mining forest minerals & & \\
\hline & Sand & Y & \\
\hline & Clay & $\mathrm{Y}$ & \\
\hline & Growing food crops (illegally) & $\mathrm{Y}$ & Y \\
\hline & Worship and cultural practices & Y & Y \\
\hline \multirow{3}{*}{$\begin{array}{l}\text { Private } \\
\text { plantations }\end{array}$} & Women allowed to collect firewood after harvesting but with permission & & Y \\
\hline & Grazing of animals & $\mathrm{Y}$ & \\
\hline & Cutting of trees & $\mathrm{Y}$ & \\
\hline \multirow[t]{4}{*}{ Farm forests } & Collecting firewood & & Y \\
\hline & Fruits & & Y \\
\hline & Grazing of animals & $\mathrm{Y}$ & \\
\hline & Cutting of trees for timber and poles for sale & $\mathrm{Y}$ & \\
\hline \multirow{9}{*}{$\begin{array}{l}\text { Communal } \\
\text { (natural) }\end{array}$} & Collecting firewood for home use & & Y \\
\hline & Collecting water & & Y \\
\hline & Making charcoal and cutting firewood with permission & $\mathrm{Y}$ & \\
\hline & Collecting medicinal materials & $\mathrm{Y}$ & $\mathrm{Y}$ \\
\hline & Cutting poles & $\mathrm{Y}$ & \\
\hline & Collecting arts and crafts materials & & Y \\
\hline & Collecting forest foods (mushrooms and fruits) & & Y \\
\hline & Collecting coffee seedlings & Y & \\
\hline & Worship and cultural practices & $\mathrm{Y}$ & $\mathrm{Y}$ \\
\hline
\end{tabular}


who work on food security, health, agriculture and provision of loans for small-scale enterprises.

Three communities reported that they actively participate in trainings and seminars related to tree planting and nature conservation offered by external actors, especially NGOs, researchers and extension agents. These meetings are not regular but depend on the number of NGOs operating in the area and activities by various NGOs and researchers. Two communities reported that they meet once a week during the rainy seasons to plan for tree planting. Three communities meet quarterly, while two reported they never meet to discuss issues related to forests; this is the case in areas where there is no NGO working on forestry issues.

Since external agents initiate most of the meetings to discuss forestry issues, communities rarely decide what is to be discussed. Members of the community working on a joint project, however, may influence a meeting's agenda. For example, members working on a community nursery project organise regular meetings to discuss issues related to management, e.g. provision of labour, space and how to share the benefits. The following are examples of some of the most common decisions made at the village meetings in relation to forest and tree management:

- Identifying tree species to be planted on-farm and in the degraded forests.

- Generating income through other activities.

- Controlling illegal harvesters.

- Lobbying for support from government and NGOs.

- Managing forest fires.

- Marketing forest and agricultural produce.

Attendance of women in village meetings was reported to be high in most communities. In meetings organised by external agents in settlements, only one community ranked attendance and participation of women as fair. The others ranked women's attendance and participation at meetings as good to very good. In this region of central Uganda, where women have high levels of literacy, cultural practices permit them to express their opinions freely and participate in decision making. External actors keep records of attendance and minutes.
Individuals/subgroups reported by communities to be most influential and in control of decision making in most meetings include:

- Facilitators (organisers) of the meetings based on the resource envelope and project activities of the $\mathrm{NGO}(\mathrm{s})$.

- Village leaders.

- Consensus (mostly in meetings to discuss joint project activities).

The communities in Rakai District had the highest number of contacts with external actors followed by Masaka and then Mpigi. NGOs in the study area whose activities included tree and forest management were:

- Vi-agro forestry - providing tree seeds and seedlings, capacity building in seed collection, tree nursery establishment, tree planting and tending, etc., in all study sites.

- Nature Uganda - mitigating wetland degradation by promoting projects such as piggery, poultry and tree planting in Masaka.

- Rubaga Rotary Club - providing clean water, energy conservation stoves and improved seeds in Mpigi district.

- Busoga Trust Fund - promoting awareness of health and sanitation issues.

- The AIDS Support Organization (TASO) building capacity for prevention of HIV/AIDS and care for the sick.

- Makerere University, Faculty of Forestry and Nature Conservation - community training and research in collaborative forest management.

- National Forest Authority - promoting awareness about collaborative forest management and user rights.

- Caritas - providing fruit tree seedlings.

- National Agricultural Advisory Services - building capacity and funding agricultural enterprises.

- World Vision - providing assistance to schools, as well as basic health care.

- District Forest Services - planting on-farm trees and managing private natural forests.

- Farm Income Enhancement and Forest Conservation (FIEFOC) - providing tree seedlings. 
Although extension services by government agencies are limited, most communities have linkages with external actors that provide both funding and practical skills at the grassroots level to enhance rural livelihoods. However, there are limited cross-community linkages to enhance farmer-tofarmer learning.

Most communities were aware of human rights, rights of children and women's rights, but not of rights to participate in forest management. All, however, were aware of rights of individuals to have private forests (both planted and natural) and that they could not access these resources without the owner's permission. In communities where we did not find formal associations, people were not aware that the law governing forests in Uganda had changed to encourage more community participation. They were, however, aware that the forestry department had been transformed into another organisation. The other issue was that communities could not distinguish between NFA, MWE and DFS staff.

Communities with no formal forest user-group associations had limited opportunities to discuss and decide on issues related to forest management. Forestry officials (both NFA and DFS) rarely hold meetings with these communities. According to Bina Agarwal's typologies in participatory exclusions (2001), these communities had minimal or nominal formal participation: almost no interaction between local stakeholders and managing institutions. No doubt, these communities had indigenous, informal forestmanagement activities that everyone engaged in.

Most members of informal forest user-groups were not aware that a number of enabling forest laws and forest frameworks allow them to participate in the formal management of forest resources. Most communities have contact with external actors (mostly NGOs). However, some of the external actors fund projects aimed at improving agriculture production - provision of improved agricultural seeds, goats, pigs and cows and rarely fund forest-management activities.

No doubt access to forest resources in the study area is influenced by land- and forest-tenure and gender. In government forest reserves, both men and women can only harvest non-timber forest products legally. Men own private forests (both natural and planted) and often women do not have access to these resources except for harvesting of firewood (after the men have harvested the timber and poles). However, women readily access firewood and fruit trees growing on family land holdings. In planted forests, access rights are restricted to family members.

We propose the following strategies for enhancing community/women's participation in areas with no formal forest user-groups:

- Assist forest-adjacent communities to set up formal forest associations.

- Establish grassroots projects, which are attractive to women, e.g. more labour-saving projects that enhance food and fuel wood security, as well as soil and water conservation.

- Initiate affirmative action programmes in schools to create a critical mass of educated women.

- Use local languages in gender sensitisation and awareness programmes on radio and TV.

- Set up grassroots-based NGOs with affirmative action programmes.

In the following section, we report on the extent that gender features in local councils/committees for forest/environmental management in the study districts. We analyse decisions of district and subcounty council, especially in relation to forest use and management. We also assess how often local communities, especially women, channel issues, questions and complaints to the local council committees.

\subsection{Extent to which gender features in local councils/committees for forest/ environmental management in the study districts}

The National Forestry and Tree Planting Act 2003 established District Forest Services (DFS). Supervised by the district councils, DFS manages the local forest reserves and oversees sustainable management of forests on private and communal land. In addition, DFS advises farmers on agroforestry practices and woodlot/plantation establishment. The district and sub-county councils, through the production and environment committees, have a mandate to:

- Formulate and enact district bylaws affecting the environment and forest sector.

- Develop district forestry-development plans and mobilise funding to implement the plans. 
- Coordinate cross-sectoral linkages relating to the management of the environment and natural resource base.

Committees were established after the enactment of the Resistance Councils and Committees Statute of 1987 and were legally strengthened by the Local Government Act of 1997 (Figure 2). Thus committees have been in existence since the devolution of decision making powers to local governments. The production committee, for example, makes policies and oversees all the production sub-sectors in the district. The majority of respondents interviewed were elected councillors sitting on the production committees at the district and sub-county levels. Other respondents were technical personnel who sit on the production committees as unofficial members (Table 10).

By law, local council committees should be composed of at least $30 \%$ women. Asked about the composition of the production committees on which they serve, about $35 \%$ of respondents reported there are more women than men (Table 11 ), while $46 \%$ reported more men than women; only $11.5 \%$ reported equal numbers of men and women.

With the exception of technical ex-officials who are not affected by elections, the composition of the committee changes every five years following elections. Thus most members who have served for five years or less were elected councillors, while those respondents that have served for more than five years were mostly technical persons employed by local government on a permanent basis. Therefore, the technical unofficial members provide both the technical knowledge and institutional memory to the committees.

Table 10. Composition of respondents interviewed

\begin{tabular}{ll}
\hline Committee name & $\%$ \\
\hline Elected councillors & 77 \\
Technical personnel & 23 \\
Males & 62 \\
Females & 38 \\
\hline
\end{tabular}

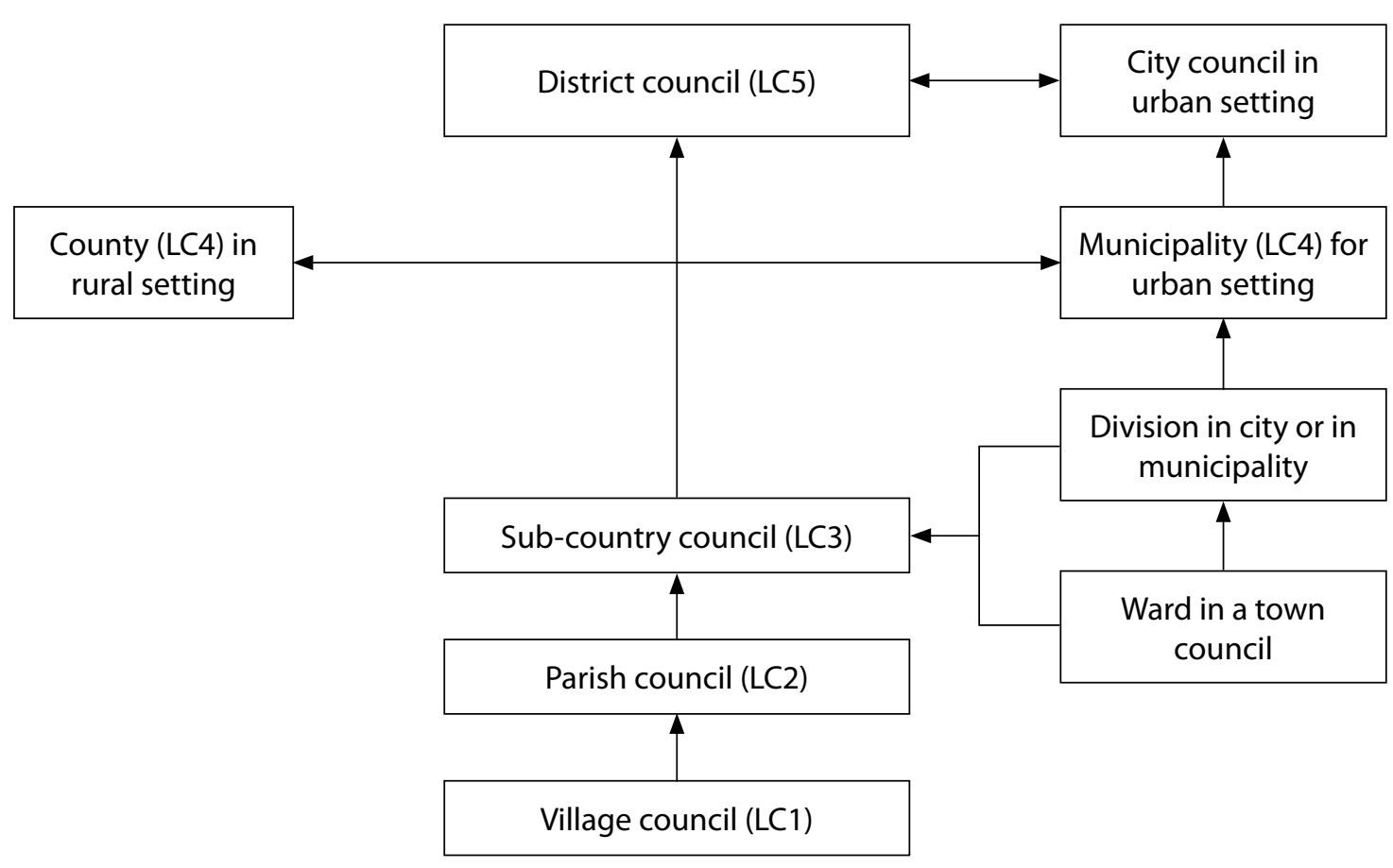

Figure 2. Local government structure in Uganda following the 1997 Local Government Act 
Table 11. Gender composition of committees where respondents serve

\begin{tabular}{lc}
\hline Gender composition of committees & $\%$ \\
\hline More than 50\% women & 35 \\
More than 50\% men & 46.2 \\
Equal number of women and men & 11.5 \\
Respondents not certain of gender & 7.3 \\
composition of their committee & \\
Total & 100.0 \\
\hline
\end{tabular}

The councillors reported that the production committee was the most active at both the subcounty and district level, partly because it brings together all the natural resources sectors, including agriculture, forestry, marketing, fisheries, lands and veterinary. In addition, forestry issues are also debated in other committees such as the NAADS; gender and community development; technical planning; and finance, planning and economic development. Technical staff from the Directorate of Natural Resources sits on these committees as well.

Most respondents (81\%) reported that committee meetings are convened by the chairperson after consulting the technical unofficial members and the Senior Accountants Secretary (who confirms the availability of funds to pay allowances to councillors). Occasionally, the chairperson to council (formally called Speaker) may convene a meeting.

The technical persons provide technical guidance to council, sitting on committees by virtue of their positions in the districts. 'Nonofficial' members do not hold voting rights. About $32 \%$ of councillors opted to serve on committees where they have interest, knowledge or experience. Some councillors (11\%) opted to sit on committees to represent Buganda Kingdom and Buganda government interests in which the study districts are located. No respondents reported that they directly represented stakeholders in the environment and forest sub-sector.

Councillors are paid an allowance every time the committee sits. The technical persons are paid a monthly salary, but may receive a lunch allowance if the committee sits for a whole day. The production committee sits at least once a month at both the district and sub-county levels. Unlike other committees, the production committee meets regularly because the central government - through conditional grants under the NAADS programme and FIEFOC pilot projects - pays allowances.

The production committee's most important activities related to the environment include planning and budgeting, making recommendations for funding for tree planting and forest reservation and making environmental bylaws (see Table 12). The committee's major activities as reported by respondents are summarised below in descending order of importance:

1. Support planning.

2. Review performances.

3. Discuss department budget and make District Development Plans.

4. Monitor and evaluate production sub-sector projects and activities.

5. Recommend funding, tree planting and forest reservation.

6. Make environmental bylaws.

Other committees that conduct activities related to the forest sector include NAADS, which trains farmers in modernisation of agriculture, tree planting and agroforestry practices. Activities carried out by the gender and community development committee related to the environment include capacity building in gender and community-livelihood issues and identifying community needs and strategies to address those needs. The technical committee provides technical support to the production committee and drafts policies and bylaws.

All respondents reported that committees make decisions by consensus. After detailed explanation of the issues by technical persons, the councillors freely discuss the motion under discussion. All members, including women, are given an opportunity to contribute to the motion until consensus is reached. Respondents reported that making decisions by consensus prevent conflicts within the committee since decisions are commonly owned. In some cases, however, secret voting takes place on contentious issues.

The respondents reported several forest-related decisions made by committees over time. They touch on issues ranging from tree planting, forest protection and conservation to forest-law enforcement and energy-saving stoves. Promotion of forest conservation and community tree planting recorded the highest 
Table 12. Mandate of various committees

\begin{tabular}{|c|c|}
\hline Committee name & Why committee was created \\
\hline \multirow[t]{11}{*}{ Production } & Plan for various departments in the natural resources sector \\
\hline & Promote environmental conservation \\
\hline & Receive, debate and improve natural resources sector work plans \\
\hline & Increase agricultural productivity \\
\hline & Lobby for support from councillors \\
\hline & Budget and finance for natural resources sector \\
\hline & Set and follow production issues \\
\hline & Formulate policies on production, marketing of natural resources \\
\hline & Monitor and evaluate production projects and activities \\
\hline & Formulate ordinances and bylaws \\
\hline & Promote forestry and tree-planting initiatives \\
\hline \multirow[t]{5}{*}{ NAADS } & Transact business on behalf of the NAADS secretariat \\
\hline & Monitor and evaluate NAADS activities \\
\hline & Help implement NAADS projects and activities \\
\hline & Promote formation of farmer groups \\
\hline & Provide and promote cross-cutting agricultural services \\
\hline \multirow[t]{2}{*}{ Gender and community development } & Promote social and community development \\
\hline & Promote forestry and tree-planting initiatives \\
\hline \multirow[t]{2}{*}{ Technical planning } & Debate and approve annual budgets and work plans \\
\hline & Oversee sector performance of the various sub-sectors \\
\hline Finance, planning and economic development & Oversee sector performance of the various sub-sectors \\
\hline
\end{tabular}

response (69\%); making bylaws to observe national Environmental Days celebrated with tree planting at institutions such as schools, district and sub-county headquarters recorded the lowest response (4\%).

Committees seem to give tree planting more attention (Table 13), and this in response to the nation-wide concern about deforestation and degradation of forests in and outside protected areas, as well as the dependency on fuelwood. In Uganda, private forests or forests outside protected areas comprise $70 \%$ of national forest cover. This implies that most initiatives to promote forestry occur on private lands outside of forest reserves.

The most influential actors in agenda-setting are normally the technical persons $(\mathrm{N}=20)$. These include sector heads of NAADS; Director of Natural Resources, Production, Lands officers; DFOs and DEOs. Only six $(\mathrm{N}=26)$ respondents reported that the chairpersons influence the committee's agenda and decision making.
During the interviews, about $92 \%$ of respondents who are 'nonofficial members' on the committees (both male and female) reported being unable to influence council decisions; only $8 \%$ of councillor respondents reported being able to always influence decision making in the council. The technical persons influence councillors' decisions most of the time because they prepare documents to be discussed in council and provide technical information, often in English. Since some councillors are not fluent in English, technical staff explain the documents. In addition, technical staff lobby the councillors to support the ideas they have presented to council.

In the study, all female councillor respondents reported being able to influence some decisions in council during the last five years (Table 14). For example, in Kagamba sub-county, the woman councillor reported a committee decision to procure livestock for the parish she represented. Since the decision was debated during a dry season, she convinced council members to allocate such money 
Table 13. Forest-related decisions made in committees as reported by respondents

\begin{tabular}{lc}
\hline Decisions related to forestry & $\%$ \\
\hline $\begin{array}{l}\text { Capacity building in forest conservation and } \\
\text { tree planting in communities }\end{array}$ & 69 \\
$\begin{array}{l}\text { Forest patrols, revenue collection and } \\
\text { enforcement of forest laws }\end{array}$ & 35 \\
$\begin{array}{l}\text { Promotion of trees for food security and } \\
\text { fuelwood }\end{array}$ & 31 \\
$\begin{array}{l}\text { Promotion of energy conservation by building } \\
\text { capacity and making energy-saving stoves }\end{array}$ & 8 \\
$\begin{array}{l}\text { Establishment of tree nurseries in each sub- } \\
\text { county to raise tree seedlings for community } \\
\text { planting }\end{array}$ & 8 \\
$\begin{array}{l}\text { Allocation of money to buy seedlings for } \\
\text { community tree planting } \\
\begin{array}{l}\text { Organisation of an annual environment day } \\
\text { to plant trees on land owned by schools, } \\
\text { churches and local government }\end{array}\end{array}$ \\
\hline
\end{tabular}

to build community water tanks instead. She had argued that community water tanks were important because women and children have to walk long distances to collect water and it becomes worse during dry seasons when most water points dry up. In another case, the women councillors for Buwama sub-county in Mpigi district convinced members of the production committee to observe the district Environmental Day by planting trees on lands belonging to institutions, including schools and religious centres.

Table 14. Examples of decisions influenced by women councillors $(\mathrm{N}=10)$

\begin{tabular}{lc}
\hline Examples of decisions influenced & $\%$ \\
\hline More coffee and fruit trees for women & 20 \\
$\begin{array}{l}\text { Planting of soil fertility and conservation } \\
\text { trees like Calliandra on the boundaries of the }\end{array}$ & 30 \\
garden & \\
$\begin{array}{l}\text { Training of communities at grassroots level } \\
\text { Proper use of FIFOC project funds through } \\
\text { regular monitoring and evaluation of project }\end{array}$ & 60 \\
$\begin{array}{l}\text { activities } \\
\text { No increase of revenue collection from the } \\
\text { district forest estate }\end{array}$ & 20 \\
$\begin{array}{l}\text { Bylaws for environment and forest } \\
\text { conservation }\end{array}$ & 40 \\
\hline
\end{tabular}

Women who can influence decision making in council include:

- Women who sit in council as technocrats.

- Women councillors who are educated and have lobbying skills.

There are few women in these two categories in the village, parish and district councils.

\subsection{Lessons learned from the study and recommendations}

Organisations and programmes that were not forest-specific were, to some extent, aware and concerned about gender issues; several had strategies to increase women's participation in their activities.

Despite good gender and legal frameworks, however, they have low levels of gender integration and affirmative action; this may be partly explained by inadequate budgets for gender mainstreaming coupled with limited staff training in gender issues (AUPWAE 2011).

There is increasing pressure from donors to increase women's participation in forest-resource management. Projects from NGO organisations seeking funding have to address issues of gender and take into account women's needs before they are funded. From the NGO perspective, two major strategies to enhance gender in projects were (i) to build capacity for project staff to undertake gender planning, analysis and implementation and (ii) to build capacity for women in the natural resources sector by implementing affirmative action programmes in training.

Apparently, although government forestry agencies were aware of the legal requirement to integrate gender issues, gender does not feature prominently in organisational projects and programmes specifically involved in forestry. Among stakeholders in forestspecific organisations, we found gender insensitivity and unwillingness to mainstream gender issues due to inadequate appreciation of women's needs and interests. There are also limited numbers of women leaders of forest projects and programmes to articulate women's needs and desires in the forest sector (e.g. there are about 2 female District Forest Officers out of 110 positions).

Even the few women in leadership positions in the forest sector are not trained in gender and have 
not been actively lobbying for enhanced women's participation in the sector. Often, such educated women are not, in fact, particularly good at representing women's needs: their urban, elite lives are too different from the lives of rural poor women. In addition, their positions are often so tenuous that they dare not 'rock the boat'. Thus, there is need for a critical mass of women before gender issues can realistically be successfully addressed.

Although the Forest Policy supports gender integration, limited strategies have been put in place to implement the policy. The only exception is the Farm Income Enhancement and Forest Conservation project (FIEFOC), a government project that supports communities and private individuals to plant trees on farmlands and watersheds.

From NGOs and governmental perspectives, different obstacles prevent women from participating in large-scale commercial tree planting projects, management of natural forests or agroforestry practices. For example, women tend to participate less in labour- and capital-intensive tree planting and CFM projects compared to small-scale, grassroots agroforestry projects. This is attributed to limited capital, long rotation periods for timber trees and undesirable tree species being promoted by government agencies, NGOs and tree growers. Limited participation in CFM was attributed to three factors: limited benefits accruing to participating women; the desire by communities to convert forest land to agriculture; and communities unsure if they will be allowed to harvest the trees they have planted and cared for under CFM in the government forest reserves.

Major obstacles hindering women's participation in on-farm tree planting were gender disparities in land ownership, cultural norms and practices, heavy domestic work loads and limited access to credit and farm inputs, as well as provision of seedlings of tree species not preferred by women.

Women were represented in formal mixed-forest user-groups. They participated actively in association activities, guided by association constitutions that require inclusion of women in leadership. The presence of a constitution negotiated by all stakeholders, including women, empowers women and reduces gender disparities in information and awareness. Thus, the quality and extent of women's participation in decision making in forest management appear to be enhanced when women join formal forest user-groups. In addition, the presence of a large number of women in the associations enables women to discuss and express their opinion freely.

Knowledge of laws, access rights and the concept of participation were better understood among members of formal forest-associations. This could be attributed to the high level of sensitisation of association members to the new Forest Policy and Forest Act by external stakeholders such as NGOs, researchers and forest officials. Knowledge of forest laws is essential while negotiating CFM agreements with the NFA.

Women's involvement in decision making and participation in forest-association activities can further be enhanced if:

- More women can take up leadership positions in formal forest user-group associations so that they are better able to set the agenda.

- More NGOs with gender affirmative strategies can be established at the grassroots.

- More networking takes place between NGOs, not only to avoid duplication but also to enhance the capacity of small local NGOs that have no gender-trained personnel.

- More networking takes place among forest associations so that they can learn from each other.

All the communities studied depended heavily on tree and forestry resources for both subsistence and income generation. Timber, firewood, charcoal and poles were the most important products harvested by men. The most important products harvested by women were firewood, water and forest foods. Men, women and youth were all found to harvest craft materials, herbal medicines and several other NTFPs.

Forest tenure and gender determined access to forest products. There were clearly defined forest/tree resource rights in private forests, planted woodlots and on-farm trees. Due to cultural norms and practices, private forests, woodlots and on-farm trees are normally owned by men. Consequently, there is limited women's participation in the management of private and on-farm trees, as well as forestry resources. However, women access freely on-farm firewood and fruit trees. 
All members of the community freely access government forest reserves for firewood, poles and NTFPs for subsistence use. NFA and members of the forest associations (where these exist) issue permits to household members to harvest forest produce on a commercial basis.

In communities with no formal forest user-group associations, most people did not understand the concept of participation or rights in respect to forest management. Again, most of them were not aware of an enabling law that allows them to participate in the management of forest resources. This could be attributed to the lack of strategy by either the central or local governments or forest-specific institutions such as the NFA and DFS to sensitise these communities about the new Forest Policy and Act. Thus, these communities have minimal or nominal participation as there is limited interaction between local stakeholders and forest institutions.

The majority of communities studied have contact with external actors (mostly NGOs). However, some of these external actors fund projects to improve agriculture production -provision of improved agricultural seeds, improved breeds of goats, pigs and cows - and rarely fund forest-management activities. Some communities reported that they actively participate in trainings and seminars related to nature conservation offered by NGOs, researchers and extension agents. Although these seminars are not regular, they have helped communities build capacity, especially that of women in the management of different natural and financial resources. Women in many communities belong to several women's groups, a condition for accessing loans under the NAADS programme. With loans from micro-finance institutions, women are able to purchase land, cows and trade in several agricultural commodities in addition to paying for school fees for their children.

The Local Government Act 1997 envisioned that local communities would be able to participate in decision making on environment and forestry issues through village councils and through councillors elected to serve in parish, sub-county and district councils. For the last 10 years, village councils have been dormant and yet most women would have had access to them since meetings would normally be held in villages close to their households. Although the sub-county and district councils are still functioning, these arenas are far removed from local women. People in local communities, especially women, have limited access to these committees. Due to financial constraints that inhibit consultations, there are few mechanisms for councillors to report to communities regularly, except through social functions. Consequently, local communities, and especially women, rarely channel issues, questions and complaints about the management of forestry resources to the sub-county and district committees.

Although districts have budgets for the creation of gender awareness and gender mainstreaming, funds allocated are too small to make an impact. For example, the budgetary allocation in Maska district to natural resources and gender for 2010-11 was USD 25000 (0.0047\% of district budget) and USD $51000(0.009 \%$ of district budget $)$ respectively (Masaka DDP 2010-2013).

Women made up 5\% of technical and political leadership positions in all three study districts. This poor representation affects women's ability to set the agenda and influence decision making in the council. Thus, there is a need for affirmative gender action both at district and sub-county levels (see Table 15).

Absence of gender focal persons as required by law at the districts and sub-county level makes it difficult to implement gender policy in the districts. At sub-county levels, most Community Development Officer positions mandated to mainstream gender are vacant. At the district level, these same positions in Masaka and Mpigi districts were occupied by officers who were also acting in other portfolios. There are, therefore, very few technical personnel with skills to spearhead the gender mainstreaming process at the district and sub-county levels. We recommend that Community Development Officer positions at all levels be filled and officers trained in gender analysis so they are able to collect gender disaggregated data for planning, capacity building and budgeting.

Environmental committees at parish, sub-county and district levels included women. Most of these environmental committees are non-functional. Yet these committees at the grassroots provided avenues for local communities, especially women, to participate in discussion and decision making in respect to the environment in general and forests in particular. 
Table 15. Analysis of gender issues in the districts and what can be done to improve women's participation

\begin{tabular}{ll}
\hline Key Gender Concerns & Effects \\
\hline $\begin{array}{l}\text { Inadequate knowledge and skills on } \\
\text { gender equity issues }\end{array}$ & $\begin{array}{l}\text { Resource allocation does not addre } \\
\text { male and female concerns equitab }\end{array}$ \\
$\begin{array}{ll}\text { Low budgeting and allocation of } \\
\text { funds to mainstream gender issues }\end{array}$ & Poor mainstreaming of gender \\
$\begin{array}{l}\text { The revised gender policy is not } \\
\text { adequately disseminated within } \\
\text { various local government councils }\end{array}$ & $\begin{array}{l}\text { Inadequate/ Lack of knowledge } \\
\text { on gender policy provisions } \\
\text { by councillors of various local } \\
\text { government tiers }\end{array}$
\end{tabular}

Inadequate capacity to do gender mainstreaming in sub-counties.

\begin{abstract}
Absence of gender focal persons as required by law at district and subcounty levels

Poor recruitment of women in political and technical leadership positions
\end{abstract}

Limited number of technical persons to spearhead the gender mainstreaming process at the subcounty level

Poor implementation of gender policy and strategies in districts

Marginalisation of women's issues in policies and administrative structures

\section{Strategies}

Train all sector heads, heads of departments and political leaders on gender issues, including equity budgeting

Increase budgetary allocation for gender programme

- Disseminate the Uganda gender policy to district and sub-county technical staff and political leaders

- Distribute copies of the policy to all sectoral departments.

- Translate the policy into local languages

Ensure participation of district and sub-county staff in generation and use of gender-disaggregated data

- Engender the data-collection tools

- Train community development officers in gender analysis

Fill vacant gender positions at district and sub-county levels

Increase opportunities for women to occupy political and administrative positions through affirmative action
Although gender equality and equity tend to feature prominently in existing government policies and programmes (AUPWAE 2011) the revised gender policy is not adequately disseminated within local government. There is inadequate/lack of knowledge about gender policy by both technocrats and councillors at both the district and sub-county levels. There is a need for the Ministry of Gender, Labour and Social Affairs, as well as for NGOs with genderbiased grassroots projects, to disseminate the Uganda gender policy to district and sub-county technical staff and political leaders. In addition, the Ministry should train the district and sub-county technical staff and political leaders in gender issues, including equity budgeting.

Due to the non-functioning of the environment committees at the sub-county and district levels, issues concerning forestry are discussed in the production and other council committees. The production committee deals with a wide range of issues including agriculture, lands, wetlands and veterinary. Forestry issues are not regularly debated since forestry is not a priority sector compared to agriculture and lands.

\subsection{Conclusions}

The study revealed that organisations and programmes that were not forest-specific were to some extent aware and concerned about gender issues; several had strategies to increase women's participation in their activities. On the other hand, although some government forestry agencies were aware of the legal requirement to integrate gender, organisational projects and programmes specifically involved in forestry do not prominently feature gender issues.

Low levels of gender integration and affirmative actions within organisations, programmes and in local governments may be partly explained by these factors: inadequate budgets for gender mainstreaming coupled with limited staff training in gender issues; 
limited numbers of women in leadership of forest projects and programmes to articulate women's needs and desires in the forest sector; and gender insensitivity by policy makers and professionals in the forest sector.

The Forest Policy supports gender integration, but limited strategies have been put in place to implement it. Currently, women can participate in management of government forest reserves through CFM arrangements. We found women participated actively in formal forest-association activities under CFM, guided by association constitutions that require inclusion of women in leadership. Thus the quality and extent of women's participation in decision making in forest management appear to be enhanced when women join formal forest usergroups. Knowledge of laws, access rights and the concept of participation were also better understood among members of formal forest user-group associations; in communities without these formal associations, most people did not understand the concept of participation or rights in respect to forest management.

The major obstacles hindering women's participation in on-farm tree planting and commercial plantation initiatives are gender disparities in land ownership; cultural norms and practices; heavy domestic work loads; limited access to credit and farm inputs; and provision of seedlings of tree species not preferred by women.

The Local Government Act 1997 envisioned that local communities could participate in decision making about the environment and forestry issues through village councils and through the councillors elected to serve in parish, sub-county and district councils. However, most of these local government organs have been dormant over the last 10 years. Only the district and sub-county councils are still functioning and yet most women have no access to them.

Most communities studied have contact with external actors (mostly NGOs). However, the majority of NGOs fund projects aimed at improving agriculture production (such as provision of improved agricultural seeds and improved breeds of goats, pigs and cows); only a few fund forest-management activities and nature conservation. Women in many communities belong to several women's groups funded by NGOs. Through these groups, women can attend capacitybuilding seminars and access loans from micro-finance institutions. Equipped with better information and finances, women may be in a better position to participate effectively in the management of forest resources in the country. 


\section{References}

AUPWAE 2011 A study of the natural resource management policy, legal and institutional frameworks: past and present projects in relation to gender and the role of women in forest management in Uganda. Draft report by Association of Uganda Professional Women in Agriculture and Environment for CIFOR.

Agrawal, A., and A. Chhatre 2006 Explaining success on the commons: community forest governance in the Indian Himalaya. World Development 34(1):149-166.

Agrawal, A., G. Yadama, R. Andrade, and A. Bhattacharya 2004 Decentralization, community, and environmental conservation: joint forest management and effects of gender equity in participation. Collective Action and Property Rights (CAPRi) Working Paper No. 63. International Food Policy Research Institute, Washington, D.C., USA.

Agarwal, B. 2001 Participatory exclusions, community forestry, and gender: an analysis for south Asia and conceptual framework. World Development 29(10):1623-1648.

Banana, A.Y. and Gombya Ssembajjwe, W. 2000 Successful forestry management: the importance of security of tenure and rule enforcement in Ugandan forests. In: Gibson, C., Mackean, M. and Ostrom, E. (eds). People and Forests: Communities, Institutions, and Governance. MIT Press, Cambridge, USA.

Banana, A.Y., Vogt, N., Bahati, J. and GombyaSsembajjwe, W. 2007 Decentralized governance and ecological health: why local institutions fail to moderate deforestation in Mpigi district, Uganda. Scientific Research and Essay 2(10): 434-445.

Banana, A.Y., Buyinza, M., Luoga, E. and Ongugo, P. 2010 Emerging local economic and social dynamics shaping East African forest landscapes. In: Guido, M., Katila P., Alfaro, R.I., Kanninen, M., Labovikov, M. and Varjo J. (eds.) Forests and Society - responding to global drivers of change, IUFRO World Series 25: 315-335. Global Network for Forest Science Cooperation, Vienna.
Barbour, M.G., Burk, J.H. and Pitts, W.D. 1987 Terrestrial plant ecology. Benjamin/Cummings, Menlo Park, USA.

Buyinza, M. and Naguula, A. 2007 Adoption of agroforestry technology and land conservation strategies in the highlands of southwestern Uganda. Makerere University Research Journal 2: $13-24$.

FAO 2007 State of the world's forests. Food and Agriculture Organization of the United Nations (FAO), Rome.

Forest Department 2003 National biomass study Technical Report of 1996-2003. Ministry of Lands, water and Environment, Republic of Uganda.

Howard, P.C 1991 Nature conservation in Uganda's tropical forest reserves. Union for the Conservation of Nature (IUCN), Gland, Switzerland.

Howard, P.L. and Nabanoga, G. 2007 Are there customary rights to plants? An inquiry among the Baganda (Uganda), with special attention to gender. World Development 35 (9): 1542-1563.

Kugonza, A., Buyinza, M. and Byakagaba, P. 2009 Linking local communities, livelihoods and forest conservation in Masindi district, northwestern Uganda. Research Journal of Applied Sciences. 4 (1): 10-16.

Muhereza, F. 2006 Decentralizing natural resource management and the politics of institutional resource management in Uganda's forest subsector. Africa Development 31(2): 67-101.

Mwangi, E., Meinzen-Dick, R. and Sun, Y. 2011 Gender and sustainable forest management in East Africa and Latin America. Ecology and Society 16(1): 17-25.

Masaka District Planning Department 2010 Masaka District Development Plan 2010-2013. Ministry of Local Government, Republic of Uganda

Namaalwa, J., Gombya-Ssembajjwe, W.S. and Ole, H. 2001 The profitability of deforestation in Uganda. International Forestry Review 3(4): 299-306.

Obua J., Banana, A.Y. and Turyahabwe, N. 1998 Attitudes of local communities towards forest 
management practices in Uganda: the case of Budongo forest reserve. Commonwealth Forestry Review 77(2): 113-118.

Ostrom, E. 1998 The international forestry resources and institutions research programme: A methodology for relating human incentives and actions on forest cover and biodiversity. In: Dallmeier F., and Comiskey, J.A. (eds.) Forest biodiversity in North, Central and South America, and the Caribbean: research and monitoring. Man and the Biosphere Series 21: 1-28. UNESCO, Paris, Parthenon, New York.

Reinikka, R. and Collier, P. 2001 Uganda's recovery: the role of farms, firms, and government. International Bank for Reconstruction and Development, World Bank, Washington, DC.

Republic of Uganda 1998 The Land Act. Entebbe, Uganda.

2000 National Forest Plan. Entebbe, Uganda.

2001 National Forest Policy. Entebbe, Uganda.

2003 The National Forestry and Tree Planting Act. Entebbe, Uganda.
Rocheleau, D. and Edmunds, D. 1998 Women, men and trees: gender, power and property in forest and agrarian landscapes. World Development 25(8):1351-1371.

Turyahabwe, N., Geldenhuys, C., Watts, S. and Banana, A.Y. 2006 Technical and institutional capacity in local organisations to manage decentralised forest resources in Uganda. Southern African Forestry Journal 208: 63-78.

UBS (Uganda Bureau of Statistics) 2002 Population census 2002. Ministry of Planning and Economic Development, Kampala, Uganda.

Vogt, N.D., Banana, A.Y., Gombya-Ssembajjwe, W. and Bahati, J. 2006 Understanding the longterm stability of West Mengo forest reserve boundaries. Ecology and Society 11(1): 38-48.

Waiswa, D., Prisley, S.P., Gombya-Ssembajjwe, W.S., Banana, A.Y. and Bahati, J. 2011 Decentralized forest management in Uganda: local communities' participation and forest sustainability. Paper to the 13 th meeting of the International Association for the Study of the Commons (IASC). Hyderabad, India, 12-15 January 2011. 


\section{Annexes}

\section{Annex 1. Criteria for site selection}

\begin{tabular}{|c|c|c|c|}
\hline \multirow[t]{2}{*}{ District } & \multicolumn{3}{|c|}{ Settlements and Property Regime of Adjacent Forests } \\
\hline & Government Forest Reserve & Private & Communal \\
\hline \multicolumn{4}{|l|}{ Mpigi } \\
\hline \multirow[t]{3}{*}{ Low density of NGOs } & Nkinga (Kizikibi Forest) & Kiziko & Mayungwe (Mbogo Forest) \\
\hline & Gombe town council & (Najjakulya) & \\
\hline & & Kibibi S/C & \\
\hline \multirow[t]{2}{*}{ High density of NGOs } & Ndugu LC1 (Mpanga forest) & Mbazzi (Namungo Forest) & Katebo (Magezigoomu Forest) \\
\hline & Mpigi town council & Muduma S/C & Buwama S/C \\
\hline \multirow{6}{*}{$\begin{array}{l}\text { Masaka } \\
\text { High density of NGOs }\end{array}$} & Bukeri & Kyambazi-Kabaale Sekandi & Bukeeri Tree Planting \\
\hline & (Nabukonge Forest Reserve) & Private Plantation & Association \\
\hline & Buwunga S/C & KyanamukakaS/C & Buwunga S/C \\
\hline & Kagologolo & & \\
\hline & Kajjude Forest & & \\
\hline & KyanamukakaS/C & & \\
\hline \multirow[t]{4}{*}{ Low density of NGOs } & Lwengo LC I & Lwebidali village (Malongo & \\
\hline & (Lwengo Forest Reserve) & $\mathrm{S} / \mathrm{C})$ & \\
\hline & Lwengo town council & 5. Farm Forests & \\
\hline & & Kyazanga Town council & \\
\hline Rakai & Katera LC I & Kigazi LCI & Nalubega LCI \\
\hline \multirow[t]{2}{*}{ Low density of NGOs } & Sango Bay Forest & Tukwatirewamu Forest & Nalubega Community Forest \\
\hline & Kyebe S/C & $\begin{array}{l}\text { Group Planting trees on a } \\
\text { government forest reserve }\end{array}$ & Kyebe S/C \\
\hline \multirow[t]{7}{*}{ High density of NGOs } & Note that communities in & Kizira Village & Kampisi Mweruka LCI \\
\hline & Kizira and Kampisi Mweruka & Kizira Coffee Farmers & Kwekulakulanya Tree Planting \\
\hline & LC I are located on a central & Association & Project \\
\hline & forests reserve & Kagamba S/C & Kagamba S/C \\
\hline & & Kajjoki LCl & \\
\hline & & Kamuswaga's Forest & \\
\hline & & Rakai Town council & \\
\hline
\end{tabular}


Annex 2. Forest adjacent communities, the actors and state of forest studied

\begin{tabular}{|c|c|c|c|c|c|}
\hline \multirow{2}{*}{$\begin{array}{l}\text { Community/ } \\
\text { Village }\end{array}$} & \multirow[t]{2}{*}{ Forest } & \multirow{2}{*}{$\begin{array}{l}\text { State of forest } \\
\text { resource }\end{array}$} & \multirow{2}{*}{$\begin{array}{l}\text { External } \\
\text { actors in the } \\
\text { community }\end{array}$} & \multicolumn{2}{|c|}{ Nature of participation in SFM } \\
\hline & & & & Men & Women \\
\hline Ndugu & Mpanga CFR & Degraded & $\begin{array}{l}\text { Researchers, SCC } \\
\text { VI, NFA, NAADS }\end{array}$ & $\begin{array}{l}\text { Planting trees for } \\
\text { drum making on } \\
\text { farms }\end{array}$ & $\begin{array}{l}\text { Apiary, piggery, } \\
\text { agroforestry }\end{array}$ \\
\hline Nkinga & $\begin{array}{l}\text { Kizikibi - } \\
\text { Nawandagi CFR }\end{array}$ & $\begin{array}{l}\text { Heavy } \\
\text { encroachment } \\
\text { for agriculture, } \\
\text { illegal timber } \\
\text { harvesting }\end{array}$ & $\begin{array}{l}\text { Researchers, NFA, } \\
\text { LCIII/ } \\
\text { politicians }\end{array}$ & $\begin{array}{l}\text { Enrichment } \\
\text { planting }\end{array}$ & $\begin{array}{l}\text { Enrichment } \\
\text { planting }\end{array}$ \\
\hline Nabukonge & Nabukonge CFR & Degraded & $\begin{array}{l}\text { SCC VI, MTPC, } \\
\text { MADDO, NFA, } \\
\text { FIEFOC, NAADS }\end{array}$ & $\begin{array}{l}\text { Tree planting in } \\
\text { and outside CFR }\end{array}$ & $\begin{array}{l}\text { Planting fruit, } \\
\text { soil and water } \\
\text { conservation } \\
\text { trees }\end{array}$ \\
\hline Kagologolo & Kajudde CFR & $\begin{array}{l}\text { Heavy } \\
\text { encroachment } \\
\text { for agriculture, } \\
\text { illegal timber } \\
\text { harvesting }\end{array}$ & $\begin{array}{l}\text { SCC VI, MADDO, } \\
\text { NFA, NAADS }\end{array}$ & Tree planting & $\begin{array}{l}\text { Planting fruit, } \\
\text { soil and water } \\
\text { conservation } \\
\text { trees }\end{array}$ \\
\hline Lwengo & Lwengo LFR & $\begin{array}{l}\text { Eucalyptus } \\
\text { plantation, illegal } \\
\text { settlement and } \\
\text { agriculture }\end{array}$ & $\begin{array}{l}\text { DFS, FIEFOC, } \\
\text { NAADS }\end{array}$ & Tree planting & $\begin{array}{l}\text { Planting fruit, } \\
\text { soil and water } \\
\text { conservation } \\
\text { trees }\end{array}$ \\
\hline Kyazanga & $\begin{array}{l}\text { CFR but heavily } \\
\text { encroached and } \\
\text { private woodlots } \\
\text { established }\end{array}$ & $\begin{array}{l}\text { Eucalyptus } \\
\text { Woodlots }\end{array}$ & $\begin{array}{l}\text { SCC VI, LCIII/ } \\
\text { Politicians, } \\
\text { Nature Uganda }\end{array}$ & $\begin{array}{l}\text { Each household } \\
\text { involved in } \\
\text { tree planting, } \\
\text { alternative source } \\
\text { of income (goat, } \\
\text { poultry, piggery) }\end{array}$ & $\begin{array}{l}\text { Each household } \\
\text { involved in } \\
\text { tree planting, } \\
\text { alternative source } \\
\text { of income (goat, } \\
\text { poultry, piggery) }\end{array}$ \\
\hline $\begin{array}{l}\text { Kajoki and } \\
\text { Bakyala } \\
\text { Kwekulakulanya } \\
\text { Association }\end{array}$ & $\begin{array}{l}\text { Kamuswaga } \\
\text { Private Forest }\end{array}$ & $\begin{array}{l}\text { Eucalyptus } \\
\text { plantation }\end{array}$ & $\begin{array}{l}\text { DFS, SCC VI, } \\
\text { FIEFOC, NAADS }\end{array}$ & $\begin{array}{l}\text { Planting } \\
\text { commercial trees }\end{array}$ & $\begin{array}{l}\text { Planting fruit, } \\
\text { soil and water } \\
\text { conservation } \\
\text { trees }\end{array}$ \\
\hline Kiziiko & $\begin{array}{l}\text { Private natural } \\
\text { forest (Najakulya) }\end{array}$ & $\begin{array}{l}\text { Heavy harvesting } \\
\text { and crop farming }\end{array}$ & SCC VI, NAADS & $\begin{array}{l}\text { Planting } \\
\text { eucalyptus, } \\
\text { coffee and other } \\
\text { high-income } \\
\text { trees }\end{array}$ & $\begin{array}{l}\text { Planting fruit, } \\
\text { soil and water } \\
\text { conservation } \\
\text { trees }\end{array}$ \\
\hline Magezigomu & $\begin{array}{l}\text { Communal Forest } \\
\text { for }\end{array}$ & $\begin{array}{l}\text { Natural forest in } \\
\text { good condition }\end{array}$ & $\begin{array}{l}\text { NAADS, Buganda } \\
\text { Kingdom, World } \\
\text { Vision }\end{array}$ & & \\
\hline \multirow[t]{2}{*}{ Bukeeri Village } & $\begin{array}{l}\text { Nabuzaale } \\
\text { Catholic Church } \\
\text { forest and }\end{array}$ & $\begin{array}{l}\text { Natural and } \\
\text { planted pine } \\
\text { forest }\end{array}$ & $\begin{array}{l}\text { MTGC, NAADS, } \\
\text { SCC VI, FIEFOC, } \\
\text { DFS }\end{array}$ & $\begin{array}{l}\text { Community tree } \\
\text { planting }\end{array}$ & $\begin{array}{l}\text { Community tree } \\
\text { planting }\end{array}$ \\
\hline & Nabukonge CFR & & & $\begin{array}{l}\text { High- income } \\
\text { trees }\end{array}$ & $\begin{array}{l}\text { Fruit, soil } \\
\text { and water } \\
\text { conservation tree } \\
\text { planting }\end{array}$ \\
\hline $\begin{array}{l}\text { Kyambazi } \\
\text { Kabaale } \\
\text { (Akezimbira } \\
\text { Women's } \\
\text { group 18F) }\end{array}$ & $\begin{array}{l}\text { Private } \\
\text { eucalyptus and } \\
\text { pine forest }\end{array}$ & $\begin{array}{l}\text { Well- managed } \\
\text { plantations }\end{array}$ & $\begin{array}{l}\text { World Vision, } \\
\text { NAADS }\end{array}$ & $\begin{array}{l}\text { Commercial tree } \\
\text { farming }\end{array}$ & $\begin{array}{l}\text { Planting fruit, } \\
\text { soil and water } \\
\text { conservation } \\
\text { trees }\end{array}$ \\
\hline
\end{tabular}


Annex 2. Continued

\begin{tabular}{|c|c|c|c|c|c|}
\hline \multirow{2}{*}{$\begin{array}{l}\text { Community/ } \\
\text { Village }\end{array}$} & \multirow[t]{2}{*}{ Forest } & \multirow{2}{*}{$\begin{array}{l}\text { State of forest } \\
\text { resource }\end{array}$} & \multirow{2}{*}{$\begin{array}{l}\text { External } \\
\text { actors in the } \\
\text { community }\end{array}$} & \multicolumn{2}{|c|}{ Nature of participation in SFM } \\
\hline & & & & Men & Women \\
\hline $\begin{array}{l}\text { Mbazzi (Kapea } \\
\text { Farmers' } \\
\text { Association) }\end{array}$ & $\begin{array}{l}\text { Lwamunda } \\
\text { Private natural } \\
\text { Forest }\end{array}$ & Heavily degraded & NAADS, NFA & Tree planting & $\begin{array}{l}\text { Planting fruit, } \\
\text { soil and water } \\
\text { conservation } \\
\text { trees }\end{array}$ \\
\hline Kizira & $\begin{array}{l}\text { Private farm } \\
\text { forests on } \\
\text { CFR, heavily } \\
\text { encroached }\end{array}$ & $\begin{array}{l}\text { CFR destroyed } \\
\text { and replaced } \\
\text { with farm forests } \\
\text { and agroforestry } \\
\text { systems }\end{array}$ & $\begin{array}{l}\text { NFA, NAADS, SCC } \\
\text { VI }\end{array}$ & Agroforestry & Agroforestry \\
\hline Mujanjabula & Sango Bay CFR & $\begin{array}{l}\text { Good condition } \\
\text { and tree planting }\end{array}$ & $\begin{array}{l}\text { NFA, GEF, UNDP, } \\
\mathrm{NBI}\end{array}$ & $\begin{array}{l}\text { Agroforestry } \\
\text { practices }\end{array}$ & $\begin{array}{l}\text { Planting fruit, } \\
\text { soil and water } \\
\text { conservation } \\
\text { trees }\end{array}$ \\
\hline Nabukonge & $\begin{array}{l}\text { Nabukone CFR } \\
\text { and Catholic } \\
\text { Church Forest }\end{array}$ & $\begin{array}{l}\text { Good condition } \\
\text { and tree planting } \\
\text { in degraded sites }\end{array}$ & & $\begin{array}{l}\text { Agroforestry } \\
\text { practices }\end{array}$ & \\
\hline Kigazi & Sango Bay CFR & $\begin{array}{l}\text { Good condition } \\
\text { and tree planting } \\
\text { in degraded sites }\end{array}$ & $\begin{array}{l}\text { NFA, GEF, UNDP, } \\
\mathrm{NBI}\end{array}$ & $\begin{array}{l}\text { Agroforestry } \\
\text { practices }\end{array}$ & $\begin{array}{l}\text { Planting fruit, } \\
\text { soil and water } \\
\text { conservation } \\
\text { trees }\end{array}$ \\
\hline Mutegomba & Namalala CFR & $\begin{array}{l}\text { Good condition } \\
\text { and tree planting } \\
\text { in degraded sites }\end{array}$ & NFA & $\begin{array}{l}\text { Agroforestry } \\
\text { practices }\end{array}$ & $\begin{array}{l}\text { Planting fruit, } \\
\text { soil and water } \\
\text { conservation } \\
\text { trees }\end{array}$ \\
\hline $\begin{array}{l}\text { Kampiisi - } \\
\text { Mweruka }\end{array}$ & $\begin{array}{l}\text { CFR but heavily } \\
\text { encroached and } \\
\text { private woodlots } \\
\text { and homes } \\
\text { established }\end{array}$ & $\begin{array}{l}\text { CFR destroyed } \\
\text { and replaced } \\
\text { with farm forests } \\
\text { and agroforestry } \\
\text { systems }\end{array}$ & $\begin{array}{l}\text { SCC VI, NFA, } \\
\text { DFS, Buganda } \\
\text { Kingdom, MW } \\
\text { and E }\end{array}$ & $\begin{array}{l}\text { Agroforestry } \\
\text { practices }\end{array}$ & $\begin{array}{l}\text { Planting fruit, } \\
\text { soil and water } \\
\text { conservation } \\
\text { trees }\end{array}$ \\
\hline
\end{tabular}



CIFOR Working Papers contain preliminary or advance research results, significant to tropical forest issues, that need to be published in a timely manner. They are produced to inform and promote discussion. Their content has been internally reviewed but not undergone the lengthier process of external peer review.

Over the past century, the management of forest resources in Uganda has vacillated from a centralised to a decentralised approach. With the Forest Act in 1993, the country began a new round of governance reforms that devolved ownership and management of central forest reserves to local governments. Four years later, the Local Government Act transferred management functions over forest reserves to the districts and sub-counties. By 2000 , however, the deforestation rate - already the highest in eastern Africa - had accelerated.

Despite the trend toward greater participation of communities in forest management, women have been largely shut out of decision making. Yet women are important actors, depending on forest resources for subsistence, as safety nets and even for income. Through this study, the researchers wish to contribute toward improving women's tenure rights to forests through their increased participation in communityforest user-groups with regard both to decision making and livelihood benefits.

\section{Austrian}

Development Cooperation

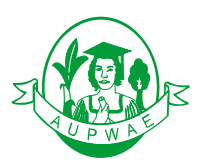

Center for International Forestry Research

CIFOR advances human wellbeing, environmental conservation and equity by conducting research to inform policies and practices that affect forests in developing countries. CIFOR is one of 15 centres within the Consultative Group on International Agricultural Research (CGIAR). CIFOR's headquarters are in Bogor, Indonesia. It also has offices in Asia, Africa and South America. 